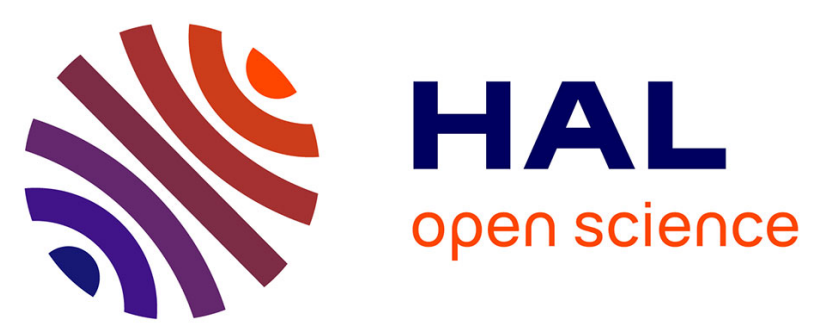

\title{
Spawning areas and migration patterns in the early life history of Squalius cephalus (Linnaeus, 1758): Use of otolith microchemistry for conservation and sustainable management
}

Bernadette Bounket, Hélène Tabouret, Pierre Gibert, Gilles Bareille, Christophe Pécheyran, Georges Carrel, Christine Argillier, Fabien Morat

\section{To cite this version:}

Bernadette Bounket, Hélène Tabouret, Pierre Gibert, Gilles Bareille, Christophe Pécheyran, et al.. Spawning areas and migration patterns in the early life history of Squalius cephalus (Linnaeus, 1758): Use of otolith microchemistry for conservation and sustainable management. Aquatic Conservation: Marine and Freshwater Ecosystems, 2021, 31 (10), pp.1-17. 10.1002/aqc.3682 . hal-03430454

\section{HAL Id: hal-03430454 \\ https://hal-univ-pau.archives-ouvertes.fr/hal-03430454}

Submitted on 18 Nov 2021

HAL is a multi-disciplinary open access archive for the deposit and dissemination of scientific research documents, whether they are published or not. The documents may come from teaching and research institutions in France or abroad, or from public or private research centers.
L'archive ouverte pluridisciplinaire HAL, est destinée au dépôt et à la diffusion de documents scientifiques de niveau recherche, publiés ou non, émanant des établissements d'enseignement et de recherche français ou étrangers, des laboratoires publics ou privés. 


\section{Spawning areas and migration patterns in the early life history of Squalius cephalus (Linnaeus, 1758): Use of otolith microchemistry for conservation and sustainable management}

\author{
Bernadette Bounket ${ }^{1}$ \\ Christophe Pecheyran ${ }^{2}$
}

\author{
Hélène Tabouret ${ }^{2}$ \\ Georges Carrel ${ }^{1}$
}

\author{
Pierre Gibert ${ }^{1}$ | Gilles Bareille ${ }^{2}$ | \\ Christine Argillier $^{1}$ | Fabien Morat ${ }^{3,4}$
}

${ }^{1}$ INRAE, UMR RECOVER, Aix-en-Provence, F13182, France

${ }^{2}$ E2S UPPA, CNRS, IPREM, Université de Pau et des Pays de l'Adour, Pau, France

${ }^{3}$ PSL Research University: EPHE-UPVD-CNRS, USR 3278 CRIOBE, Université de Perpignan,

Perpignan, France

${ }^{4}$ Laboratoire d'Excellence, CORAIL, Perpignan, France

Correspondence

Dr Hélène Tabouret, E2S UPPA, CNRS, IPREM, Université de Pau et des Pays de I'Adour, F-64053, Pau, France.

Email: helene.tabouret@univ-pau.fr

Funding information

French National Research Institute for Agriculture, Food and Environment; French Office for Biodiversity

\section{Abstract}

1. In the context of the River Rhône restoration programme, the objective of this study was to assess the dispersal and population connectivity of the European chub, Squalius cephalus (Linnaeus, 1758) in a section of the natural, free-flowing part of the lower River Rhône.

2. The elemental water signatures for $\mathrm{Sr}: \mathrm{Ca}$ and $\mathrm{Ba}: \mathrm{Ca}$ were measured at seven stations within the river section, including its tributaries and backwaters, to determine whether they could be differentiated by microchemistry. From August to October the signatures differed among three sectors of the study reach: the Rhône; the Ardèche; and the backwaters.

3. The elemental signatures of the otoliths of 178 young-of-the-year (YOY) chub from the stations were measured to assess spawning areas and identify early migratory life histories. Analyses of otolith microchemistry identified the natal origin of $95 \%$ of the fish. Sr:Ca signatures of otoliths showed early downstream migration for $30.4 \%$ of the YOY chub; however, $70 \%$ of the fish recruited relatively close to their spawning origin suggesting a potential inshore retention of fish.

4. The results showed (i) a non-negligible contribution of the tributaries and backwaters in the recruitment of fish into the main channel; and (ii) the ability of chub to migrate over several kilometres during their first few months of life.

5. This study shows that the combination of water and otolith microchemistry analyses of fish growth increases the understanding of fish life history. Moreover, the study revealed that half of the YOY fish from this river section came from the tributaries and the other half came from reproduction in the River Rhône (despite its high anthropization).

6. These methods offer promising future applications of otolith microchemistry for river management in the context of ecological rehabilitation, especially to assess the effectiveness of measures applied in the restoration of floodplain connectivity for riverine fish population conservation.

\section{KEYWORDS}

conservation, dispersal, fish, large regulated river, migration 


\section{1 | INTRODUCTION}

From global to local scales, human activities have modified Earth's terrestrial water cycle (Vörösmarty \& Sahagian, 2000) and threaten freshwater ecosystems (Dudgeon et al., 2006). Recorded freshwater species loss and predicted extinction over the years are extremely concerning (Xenopoulos et al., 2005; Arthington et al., 2016). Multiple human factors explain the long-term decline of freshwater fish populations and the progressive large-scale homogenization of fish communities (Rahel, 2007). Specifically, the intensification of catchment land-use, development and regulation of river networks has unquestionably had considerable impacts (Haidvogl et al., 2015; Bierschenk et al., 2019). The present uncoupled state of channels and floodplains is the result of a long history (Brown et al., 2018) from the early protection of settlements and improvement of navigation to the vast waterways and hydropower scheme developments. All these changes modified the water discharge and the temperature regimes, and increased the longitudinal and lateral fragmentation of rivers, restricting fish movements between functional habitats (Bunn \& Arthington, 2002; Hall, Jordaan \& Frisk, 2011).

Connectivity between habitats can be crucial at any fish lifehistory stage (Torniainen et al., 2013), to maintain genetic diversity (Faulks, Gilligan \& Beheregaray, 2011; Gouskov et al., 2016) or population size (Gido et al., 2016). Understanding the spatial and temporal patterns of fish movements is critical for effective management and conservation (Elsdon \& Gillanders, 2003a; Beger et al., 2010). In river systems with varied habitats, particular areas may act as important sources or sinks for recruitment (McDowall, Allibone $\&$ Chadderton, 2001). Therefore, assessing the contributions of these areas, and the connectivity between populations, is necessary for efficient restoration (Jansson, Nilsson \& Malmqvist, 2007; Zeigler \& Whitledge, 2010). Moreover, identifying spawning areas and migration patterns will help with a better understanding of the species' life-history traits, which is a central goal in any species conservation strategy (Takada \& Tachihara, 2009; Egan, Hickford \& Schiel, 2019).

The connectivity in fish populations has been studied by several techniques such as genetic analyses (Planes, Jones \& Thorrold, 2009; Faulks, Gilligan \& Beheregaray, 2011), tag and release methods (Mellon-Duval et al., 2010), and acoustic telemetry (Espinoza et al., 2017); however, assessing spawning areas and dispersal of early stages of fish can be quite challenging. One emerging method is the use of otolith microchemistry (Elsdon et al., 2008; Starrs, Ebner \& Fulton, 2016; Maguffee et al., 2019). Located in the inner ears of teleosts, otoliths are composed of calcium carbonate and a protein matrix. They grow daily (Pannella, 1971; Campana \& Neilson, 1985) throughout the life of the fish and store minor and trace elements (Campana, 1999) that may reflect the environmental conditions experienced by the individual fish (Bath et al., 2000; Elsdon \& Gillanders, 2004). Otoliths are metabolically inert, implying that they are not subjected to resorption (Campana \& Thorrold, 2001). As such, the chemical composition of the otolith from the primordium (nucleus/core) to the outer edge represents records of a fish's environmental life history and provides information about its origin and its migrations (Campana, 1999; Elsdon et al., 2008). The use of this powerful tool is nevertheless constrained by three assumptions: (i) the existence of chemically distinct habitats; (ii) the stability in time of the chemical signature within these habitats; and (iii) a metabolic control on the elemental integration constant over time (Kalish, 1989; Gillanders, 2002). The monitoring in time of the chemical composition of the environment, at seasonal or inter-annual scales, is often a prerequisite (Brennan et al., 2015). Despite the fact that otolith microchemistry has mostly been used in marine ecosystems or migrations between freshwater and marine environments (Daverat et al., 2005), some studies have shown promising results in freshwater ecosystems (Kennedy et al., 2002; Lazartigues et al., 2018), making this tool valuable for fisheries management and conservation (Pracheil et al., 2014).

Although pollution and overfishing contributed early to the extinction or rarefaction of many species (Hoffmann, 2005), the longitudinal fragmentation of rivers by dams had been primarily considered as the most harmful for economically valuable fish species (Liermann et al., 2012). An abundant literature documents the impacts of physical barriers on the population dynamics of iconic long-distance migratory species such as salmonids (Fullerton et al., 2010; Wolter, 2015; Lenders, 2017), clupeids, eels (Feunteun, 2002), lampreys or sturgeons (Bacalbasa-Dobrovici, 1997), as they are considered to be the most affected by these changes (Liermann et al., 2012). However, lesser known obligate riverine species, such as leuciscids, that undergo ontogenetic migrations between specific habitats, have received less attention (Lechner et al., 2014; Benitez et al., 2015; Zens et al., 2018). The lack of knowledge about the migratory behaviour of these freshwater fishes that are mainly affected by the hydraulic discontinuities of the river, especially the disruption of the transversal connectivity in regulated floodplain rivers (Schiemer \& Spindler, 1989), emphasizes the need for such information. This knowledge is all the more urgent as current analyses of long-term surveys have shown that generalist species are also under threat (Mueller, Pander \& Geist, 2018).

Habitat degradation is one of the major factors causing the decline of aquatic biodiversity (Miller, Williams \& Williams, 1989; Hickford \& Schiel, 2014). Consequently, the restoration of habitats has become a main focus in conservation efforts and environmental policy worldwide (Bernhardt et al., 2007). One of Europe's major rivers, the River Rhône is the largest in France in depth and volume, and the most highly modified for navigation, hydropower and nuclear electricity production (Olivier et al., 2009). A major ecological restoration programme has been in place on the Rhône since 1998. It aims to tackle multiple challenges, including nature conservation and restoration actions focusing on hydrological improvement and side-channel reconnection (Lamouroux et al., 2015; Piégay, 2018). The 'Plan Rhône' project has focused on dismantling the historical longitudinal and transversal engineering structures (Thorel et al., 2018): removing dykes, groynes and rip-rap protections, is intended to reactivate hydraulic and geomorphological processes to 
create new channel and riparian habitats. The deconstruction also contributes to reconnecting former functions that characterized the floodplain hydro-system, restoring migration routes for fish, and significantly extending and improving the ecological features of shore zones (Schiemer, Keckeis \& Flore, 2001) in by-passed sections of the former channels of the River Rhône.

In this context, and before the completion of important civil engineering works, the objective was to assess the dispersal and population connectivity of the European chub, Squalius cephalus (Linnaeus, 1758) in a regulated section of the lower River Rhône. The European chub is one of the most studied leuciscids in Europe. The chub is a potamodromous lithophilic species with a broad-scale distribution in European lotic fresh waters (Kottelat \& Freyhof, 2007). It can use a wide variety of habitats, lentic as well as lotic waters, and adjust to habitat alteration (Philippart \& Vranken, 1983; Keith et al., 2011). Although it has been reported that adults can move several kilometres in a single day (Capra, Pella \& Ovidio, 2018) and between 10 and $25 \mathrm{~km}$ during the spawning period (Fredrich et al., 2003; De Leeuw \& Winter, 2008), the migration of early stages and more specifically the connectivity between the spawning and nursery habitats of chub populations (particularly in large rivers) are unknown.

This study aimed to use otolith chemistry of young-of-the-year chub as a tool to investigate the spatial connectivity in a section of the lower Rhône about $50 \mathrm{~km}$ long (from Viviers pk 166 to Caderousse power plant pk 215). The three main objectives were to: (i) analyse the suitable environmental conditions in the area studied for the use of otolith microchemistry in habitat reconstruction (i.e. chemically distinct habitats, stability in time of the chemical signature and absence of metabolic control on the elemental integration); (ii) assess spawning areas (origin of fish: Ardèche, backwaters or River Rhône); and (iii) estimate the migrations of juveniles between locations (from spawning areas to sampling sites). A preliminary hypothesis was that the tributaries and backwaters would be sources of larvae and juveniles and play an essential role in the renewal of the River Rhône population. As early stages are more likely to migrate by drifting, it was assumed that movements occurred mainly downstream.

\section{I MATERIAL AND METHODS}

\subsection{Study area}

This study took place in the middle Lower River Rhône, in the reach of Caderousse created by the successive hydropower run-of-river schemes of Donzère-Mondragon and Caderousse (Figure 1). The reach of Caderousse includes the long by-passed section of the Donzère-Mondragon scheme $(29.0 \mathrm{~km})$, the reservoir of Caderousse $(11.5 \mathrm{~km})$ and the tailrace of the Bollène power plant $(11.0 \mathrm{~km}) . \mathrm{In}$ its third and downstream part, the by-passed section is joined by a large and typical Mediterranean tributary characterized by the recurrence of flash floods: the Ardèche river. The Compagnie
Nationale du Rhône provided daily discharge data for the River Rhône (gauging stations of Viviers, Saint Montan, Pont-Saint-Esprit, Chusclan) and the Ardèche river (Sauze; http://www.cnr.ttm.fr/; Figure S1).

Seven stations were studied (Figure 1): one in the right-bank tributary of the sector - the Ardèche River near Pont-Saint-Esprit (station A); one in associated backwaters of the old River Rhône the Lône of Malaubert; an old left-bank lateral channel (station B); five stations were located in the main river channel - upstream (station C), by-passed section (stations $\mathrm{D}, \mathrm{E}$, and $\mathrm{F}$ - which is also the confluence with the Ardèche River); and in the most downstream part of the Caderousse reservoir (station G). It was assumed that station B was representative of the backwaters of the floodplain. An old weir, equipped by a simple and rudimentary rock-ramp fishway, is located at the confluence of the Ardèche River and the old River Rhône. The upstream limit of the old River Rhône is the dam of Donzère (between stations $C$ and $D$ ), and the power plant and the dam of Caderousse are the downstream limits of the reach close to station G. It is also worth noting that the confluences with the Cèze and the Aigues Rivers are located downstream of the dam of Caderousse.

\section{2 | Water sampling and analysis}

To assess the spatial and temporal variability in water chemistry, samples were collected monthly during the year 2016 from all the seven stations. Water was collected at the subsurface with a bucket thoroughly rinsed three times with the station water. Immediately after sampling, the water was filtered with a 20-ml syringe through a PVDF Whatman 0.45- $\mu \mathrm{m}$ filter into an acid-washed $50-\mathrm{ml}$ sample tube. The sampled water was then acidified with $1 \mathrm{ml}$ pure nitric acid (Ultrex II, Baker, Germany), kept in the dark and refrigerated until processing.

Following Tabouret et al. (2010), element concentrations (Sr, Ba, $\mathrm{Ca}, \mathrm{Mg}$ ) were determined by inductively coupled plasma atomic emission spectroscopy (ICP-AES; Horiba, Jobin-Yvon, Japan) at the Institute of Analytical Sciences and Physico-Chemistry for Environment and Materials (IPREM, University of Pau, France). The internal standard Indium ( $2 \mathrm{mg} \mathrm{L}^{-1}$ ) was used to correct for the instrumental drift. The accuracy of the analysis was checked using the freshwater certified reference SLRS-4 (NRCC, Canada). Limits of detection, determined from blanks, were $0.137 \mathrm{ng} \mathrm{g}^{-1}$ for $\mathrm{Sr}, 0.105 \mathrm{ng} \mathrm{g}^{-1}$ for $\mathrm{Ba}, 16 \mathrm{ng} \mathrm{g}^{-1}$ for Ca and $0.001 \mathrm{ng} \mathrm{g}^{-1}$ for $\mathrm{Mg}$. The accepted recovery of reference materials ranged from $95 \%$ to $104 \%$.

\section{3 | Fish sampling, otolith preparation, age and growth rate estimations}

Among the $376 \mathrm{~S}$. cephalus below $90 \mathrm{~mm}$ (total length, TL) sampled by electrofishing (from 29 November to 2 December 
FIGURE 1 Map of the Caderousse reach, on the Lower River Rhône. Sampling locations of Squalius cephalus are represented by encircled letters. Physical barriers are shown in red circles. The arrows indicate the gauging stations. A, Ardèche; B, backwaters; C, D, E, Rhône by-passed (from upstream to downstream); F, confluence (between the Ardèche and the Rhône); G, downstream reservoir

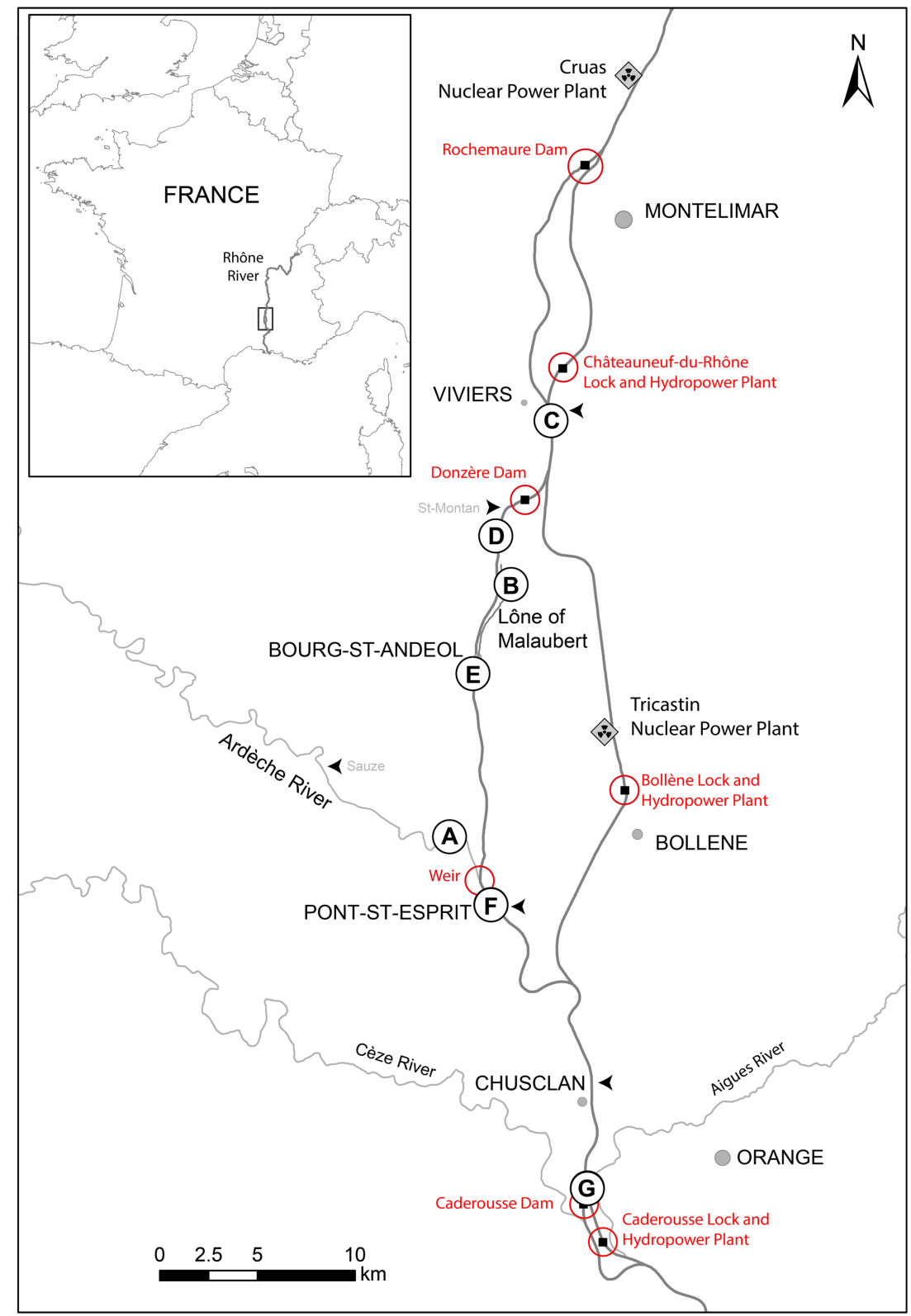

2016), a subsample of 178 was used for connectivity analyses (Supporting Information Table S1). Sampled fish were euthanized by anaesthetic overdose then kept frozen. They were defrosted in the laboratory, measured for total length and their otoliths (lapilli) were removed. Fish length ranged from 26 to $82 \mathrm{~mm}$ (mean $=50 \pm 12 \mathrm{~mm}$ ) depending on the station (Supporting Information Table S1).

Following the recommendations of Bounket et al. (2019), only lapilli were extracted, cleaned and stored dry in cryotubes for further analyses. Only the right-side otoliths were used in this study. Otoliths were embedded in epoxy resin Araldite 2020 (Huntsman, France) and mounted individually on clean glass slides using thermoplastic glue (Crystalbond ${ }^{\mathrm{TM}}$ ). To expose the daily growth increments, otoliths were ground on the frontal plane with abrasive papers (2,400 grit) and polished with diamond solutions $(0.25 \mu \mathrm{m}$; Escil; Chassieu, France) until satisfactory readability.
According to previous validation of daily growth increments in S. cephalus otoliths (Bounket et al., 2019) photographs of the sectioned otolith were taken along the anterior axis (rostrum tip) and were merged into a large image using Photostitch software (Canon; www.canon-utilities-photostitch.en.lo4d.com). A unique reading transect following the maximum growth axis was drawn on each stitched image. Using Image ( $\mathrm{NIH}$, USA), fish age was estimated by counting growth increments along the transect from the core to the outer edge, and distance between each count was incremented to estimate daily growth rates. Counts were performed twice by two independent readers. The precision of the readings was determined using the coefficient of variation (CV), as defined by Campana (2001). A first CV was calculated between both counts made by the same reader, and when this $\mathrm{CV}$ was above $5 \%$, the otolith was recounted a third time. If the three readings still resulted in a CV $>5 \%$, the sample was counted again by both readers simultaneously. If disagreement 
remained, the sample was discarded. A global CV of all readings was then recalculated.

\section{4 | Microchemical analysis}

Element concentrations in otoliths were determined by laser ablation inductively coupled plasma mass spectrometry at the IPREM (University of Pau, France) as described by Tabouret et al. (2010). Otolith samples were analysed with an IR $1030 \mathrm{~nm}$ fs laser (AlfametNovalase, France) in conjunction with a Perkin Elmer DRCII ICP-MS (Perkin Elmer, Shelton, CT, USA).

Prior to analyses the surface of each otolith was cleaned with ultrapure water $(18.2 \mathrm{M} \Omega)$ to remove any potential surface contaminants and dried before being processed. Glass standard reference materials NIST-612 and NIST-610 (National Institute of Standards and Technology, Gaithersburg, MD, USA), were used for quantification. The fish otolith powder reference FEBS-1 (National Research Council Canada, Ottawa, ON, Canada) provided quality control of the analytical accuracy. Juvenile otoliths were ablated using a single raster scan following the reading transect. Ablation started $100 \mu \mathrm{m}$ before the nucleus and crossed the core to have the initial natal information. The laser moved at a speed of $5 \mu \mathrm{m} \mathrm{s}{ }^{-1}$, with a $20-\mathrm{Hz}$ pulse rate at $15 \%$ intensity resulting in a spot size of $15 \mu \mathrm{m}$. These parameters represent the best compromise found between the spatial resolution, especially depth-wise (ablation depth $<10 \mu \mathrm{m}$; samples being very tiny and thin), and the amount of ablated material.

Focus was put on eight elements: ${ }^{7} \mathrm{Li},{ }^{24} \mathrm{Mg},{ }^{43} \mathrm{Ca},{ }^{55} \mathrm{Mn},{ }^{85} \mathrm{Rb}$, ${ }^{86} \mathrm{Sr},{ }^{138} \mathrm{Ba},{ }^{66} \mathrm{Zn}$. However, owing to the parameters constrained by the size of the samples, most of these elements were below the limit of detection. Given the water data collected, the elements $\mathrm{Sr}, \mathrm{Ba}$ and $\mathrm{Mg}$ were considered for further analyses; Mn was also used for nucleus delimitations. Elemental signatures before the hatching mark of each chub (obtained from the otolith reading) were removed from the analyses. ${ }^{43} \mathrm{Ca}$ was used as an internal standard for each ablation to check for variation in ablation yield. Limits of detection were $3.82 \mu \mathrm{g} \mathrm{g}^{-1}$ for ${ }^{86} \mathrm{Sr}, 0.11 \mu \mathrm{g} \mathrm{g}{ }^{-1}$ for ${ }^{138} \mathrm{Ba}, 0.87 \mu \mathrm{g} \mathrm{g}^{-1}$ for ${ }^{55} \mathrm{Mn}$ and $10.82 \mu \mathrm{g} \mathrm{g}^{-1}$ for ${ }^{24} \mathrm{Mg}$. The accepted recovery of reference materials ranged from $95 \%$ to $110 \%$. Elemental concentrations in otoliths were converted to elemental mass ratios (element: $\mathrm{Ca}$ ) based on the stoichiometry of $\mathrm{Ca}$ carbonate $\left(383,000 \mu \mathrm{g} \mathrm{g}^{-1}\right)$ as suggested by Campana (1999).

\section{5 | Converting elemental signature distance from the core to calendar dates}

Digital images of each otolith were also taken after the laser ablation to verify the correct overlay between reading and laser ablation transects, ensuring the accurate correlation between age/growth rate estimates and elemental signatures. Based on the width between daily increments of each fish, the distance of laser ablation from the core was converted to age (day post-hatching, dph). The elemental signature was then converted into calendar dates according to the hatching date of each fish by using linear interpolation.

\subsection{Data analysis}

Statistical analyses were performed using the software $\mathrm{R}$ version 3.5.2 (R Core Team, 2016).

To determine whether the water chemistry differed between stations, a principal component analysis was performed followed by canonical discriminant analysis on the considered chemical elements in ratio to calcium. The canonical discriminant analysis scores were plotted to visualize the differences.

Differences in elemental profiles between sampled stations were investigated using Kruskal-Wallis tests since the data did not meet homoscedasticity assumptions. Whenever significant effects were identified, pairwise comparisons using the Wilcoxon rank-sum test were performed.

An assumption was made that the otolith edge (the last period of the fish life) corresponds to the chemical signature of the water at the station where the fish was sampled. The relationships of elemental signatures between water and otolith were assessed by a linear regression model using the elemental signature of the edge of the otolith and the elemental signature of the water close to the time of capture (November). Based on previous studies (Elsdon \& Gillanders, 2005a; Yokouchi et al., 2011), to ensure that the elemental signature had time to be incorporated into the otoliths, the edge of the otolith taken into account consisted of the eight last spots (corresponding on average to $18 \pm 4$ days, according to their growth rates). The slope of the relationship between [element: $\mathrm{Ca}]_{\text {otolith }}$ and [element: $\mathrm{Ca}]_{\text {water }}$ provided an estimate of the partition coefficients ( $D_{\text {element }}$ ) between ambient water and the otolith, which quantify the degree at which elements are regulated between the environment and species-specific tissues (Morse \& Bender, 1990; Campana, 1999; Tabouret et al., 2010). The linear model was then applied to monthly records of water chemistry in order to predict theoretical/reference elemental signatures in otoliths of a resident fish for each station.

Elemental signatures of each fish were then compared with those predicted by modelling. Although simple visual comparisons might provide a better indication of habitat shifts during the life of the fish, it did not allow precise identification of discontinuities in elemental signatures and was also considered too arbitrary. Subsequently, classification and regression trees implemented in the package 'Tampo' (Vignon, 2015) were used in univariate analyses to detect shifts in Sr:Ca signatures of each otolith. To give more accurate and biologically meaningful interpretations of migratory patterns, multivariate regression trees were created using the MRT.2C function from 'Tampo' which required two conditions to allow a split in elemental signatures. A minimum number of three consecutive measures within each cluster was needed. Moreover, the minimal difference to allow for splitting was set to condition $=0.495$ : this 
threshold corresponded to the mean difference between the elemental signature of an Ardèche 'resident' profile and a backwaters 'resident' profile (taking into account that a Rhône 'resident' profile had the highest Sr:Ca signature). The beginning of the profile was used to identify the fish hatching area. Then, the detection of one or more splits in the elemental signature was first interpreted as evidence for a migration from one station to another, permitting all samples (fish) to be separated into two main categories: migratory and non-migratory fish (Figure 2).

\subsection{Ethics statements}

All relevant international, national, and/or institutional guidelines for the care and use of animals were followed. Fish were euthanized using anaesthetic overdose (eugenol) in accordance with the European Directive 2010/63/EU. Fish were collected in conformity with required authorizations for sampling for the duration of this PhD project: 2015-217-004, 2015-229-DDTSE01, 2017-124-DDTSE01 and 2017-165-0007, delivered by the prefectures.

\section{\begin{tabular}{l|l}
3 & RESULTS
\end{tabular}}

\subsection{Water chemistry}

Overall, based on the canonical discriminant analysis, four of the stations located in the main Rhône river channel (C, D, E and G) had similar water chemistry in $\mathrm{Sr}: \mathrm{Ca}, \mathrm{Ba}: \mathrm{Ca}$ and $\mathrm{Mg}: \mathrm{Ca}$ and were therefore regrouped under the same sector name: Rhône (Figure 3). The elemental signatures of the Ardèche (station $A$ ) and the backwaters (station B) were differentiated from each other and the Rhône (Figure 3) but not throughout the year (Figure S2a-c). Station F, the confluence between the Rhône and the Ardèche, had chemical properties typical of a mixture of the two sources. When comparing the water temporal elemental signature (Figure S2a-c), sectors were separated by a multi-element approach. Sr:Ca signatures of the Ardèche, backwaters and Rhône were only distinguished from each other from mid-July until mid-November, whereas Ba:Ca ratios discriminated the Ardèche from the others, and $\mathrm{Mg}: \mathrm{Ca}$ ratios discriminated the backwaters.

Not all the elemental signatures were stable throughout the year at all the stations. Although the Sr:Ca elemental signatures of the Ardèche (mean \pm standard deviation $(\mathrm{sd})=3.91 \pm 0.29 \times 10^{-3}$ ) and the backwaters (mean $\pm \mathrm{sd}=5.16 \pm 0.33 \times 10^{-3}$ ) stayed stable over the year, that of the Rhône was much more variable (mean $\pm \mathrm{sd}=5.54 \pm 1.60 \times 10^{-3}$ ) increasing to $9.63 \times 10^{-3}$ from June to September and then decreasing until December (Figure S2a). The Ardèche showed the highest values of the $\mathrm{Ba}: \mathrm{Ca}$ ratios (Figure S2b), with high variability (mean $\pm \mathrm{sd}=3.06 \pm 1.53$ $\times 10^{-3}$ ), whereas those of the backwaters (station B) were similar to those of the Rhône and were relatively stable (mean \pm $\mathrm{sd}=1.19 \pm 0.34 \times 10^{-3}$ and $1.55 \pm 0.76 \times 10^{-3}$, respectively). The backwaters showed the lowest ratios of $\mathrm{Mg}: \mathrm{Ca}$ signatures (Figure S2c), with a relatively stable signature throughout the year, with a very slight increase between August and September, while the Ardèche and the Rhône were very variable with high peaks in

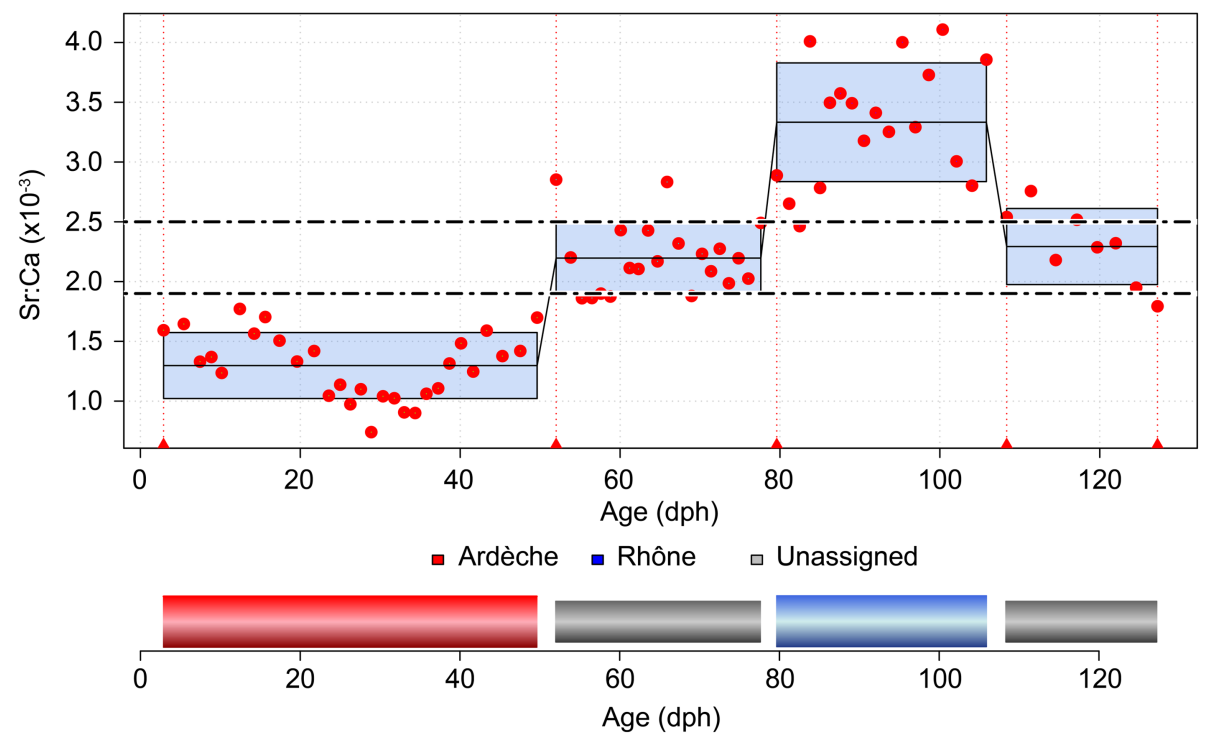

FIGURE 2 Sr:Ca ratios as a function of fish age in days post hatching (dph). Original data fitted with the corresponding piecewise constant model obtained using the R package 'Tampo': MRT (Multivariate regression trees) models with different constraint values (size, 3; condition, 0.495). The mean and standard deviation are shown for each group. The dashed lines represent the habitat condition set. The bars below the graph represent the habitat associated with the elemental signature by the model. The first group was used to identify the spawning area (the Ardèche in this example), and splits indicate migration between habitats (in this example: from the Ardèche to the Rhône). This sample (751161) was captured at station $\mathrm{F}$ (confluence between the Ardèche and the Rhône) 


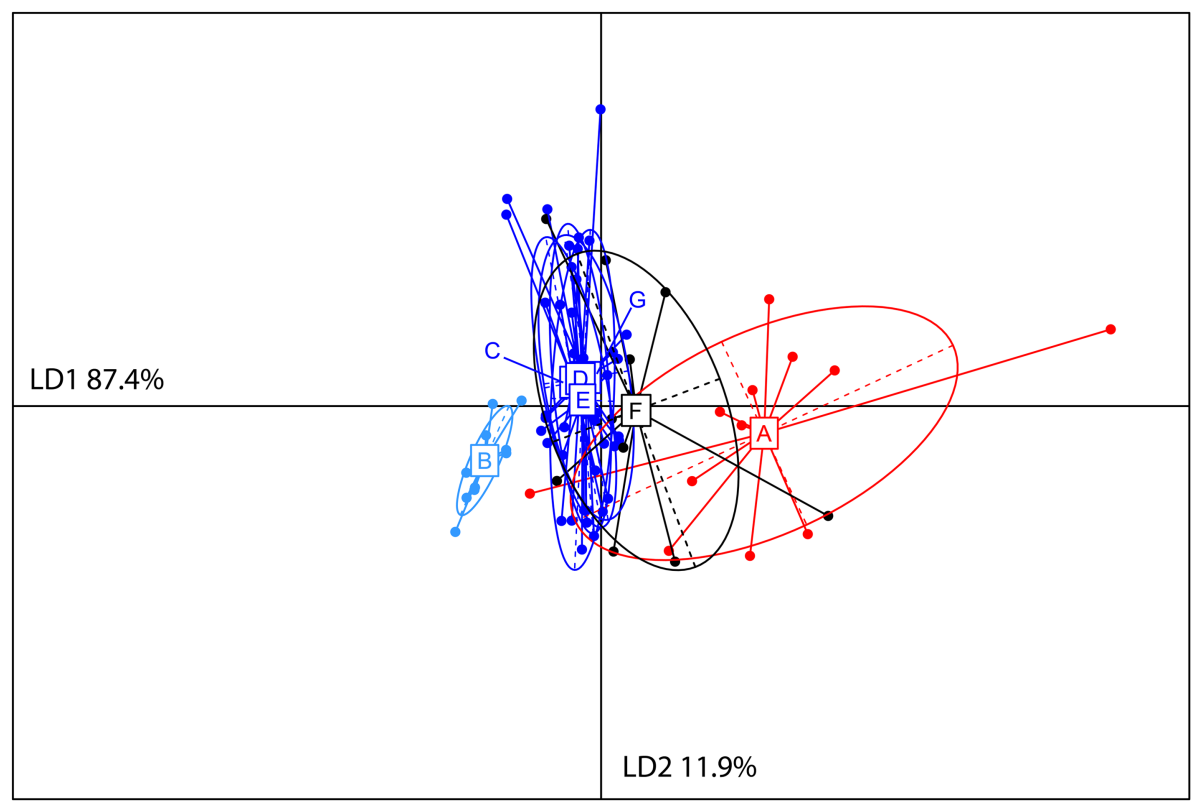

FIGURE 3 Canonical discriminant analysis performed on element concentrations ( $\mathrm{Sr}, \mathrm{Ba}, \mathrm{Mg}$ ) of monthly sampled water in 2016 of all stations studied: Ardèche (red - A); backwaters (light blue - B); Rhône (blue, C - D - E $\mathrm{G})$ : and the confluence between the Ardèche; and the Rhône (black - F). Linear discriminant (LD) functions are indicated for each axis
September (in the Rhône) and October (in the Ardèche). The elemental signatures of the confluence (station F) were similar to those of the Rhône from May to October suggesting the main contribution of the Rhône water at that time.

In general, the best period to discriminate elemental signatures from the different sectors was from August to October, which coincided with the lowest river discharge (Figure S1) and the growing period of the YOY chub collected for this study.

\subsection{Otolith elemental signatures}

The Sr:Ca ratios at the edge of the otoliths were different between the sampling sectors $\left(\chi^{2}=53.72\right.$, degress of freedom (d.f.) $=3$, $P<0.001)$. Signatures from fish sampled in the Rhône and the confluence differed significantly from those collected in the Ardèche and the backwaters as expected according to water data (Figure 4a). $\mathrm{Sr}: \mathrm{Ca}$ ratios of fish sampled in the Ardèche were also consistent with the water records as they were significantly lower compared with those from the backwaters. However, some individuals from these two sectors exhibited relatively close Sr:Ca signatures, sometimes showing overlap. The possible ambiguity in the discrimination between the two tributaries using $\mathrm{Sr}: \mathrm{Ca}$ ratios was resolved based on the $\mathrm{Ba}: \mathrm{Ca}$ ratios. Indeed, fish sampled in the Ardèche showed significantly higher $\mathrm{Ba}: \mathrm{Ca}$ ratios compared with those from the other sectors $\left(\chi^{2}=52.253\right.$, d.f. $=3, P<0.001$, Figure 4b).

The Mg:Ca ratios at the edge of the otoliths were different between sectors $\left(\chi^{2}=14.773\right.$, d.f. $\left.=3, P=0.0020\right)$ but not as expected. Whereas the water Mg:Ca signature of the backwaters was the lowest, this was not the case for the otolith Mg:Ca ratios, as they showed lower values for fish sampled in the Ardèche (Figure 4c). In addition, $\mathrm{Mg}: \mathrm{Ca}$ otolith signatures could discriminate fish of the
Ardèche from those of the Rhône but not from those of the backwaters as would have been expected from water records.

The elemental signatures of fish sampled in the confluence were very similar to those in the Rhône's for $\mathrm{Sr}: \mathrm{Ca}$ and $\mathrm{Mg}: \mathrm{Ca}$. For $\mathrm{Ba}: \mathrm{Ca}$, signatures of fish from the confluence were lower than those from the Ardèche and higher than those from the Rhône and the backwaters.

\subsection{Water-otolith relationships}

Owing to their positions in the reach, stations $F$ (Ardèche-Rhône confluence) and $\mathrm{G}$ (reservoir) might contain fish from the Rhône, the backwaters and the Ardèche resulting in too much variability in the elemental signatures; therefore, they were not considered in the analysis. Moreover, there were not enough fish from station $\mathrm{C}$ (upstream; $N=7$ ) to establish reliable elemental water/otolith relationships. Therefore, only otoliths of fish from stations A, B, D and $E$ were used to check for linear regression between water and the chemistry of the outer edge of the otolith, and to evaluate the partition coefficients of strontium and barium. The linear regression analysis ( $y=0.3958 x+0.1041, R^{2}=0.94, P=0.032$ ) showed a positive relationship between $\mathrm{Sr}: \mathrm{Ca}$ in water and in otoliths for the last month of the fish's life (Figure 5a). The intercept of the linear regression was not significantly different from $0(P=0.82)$, suggesting that the slope of the relationship is a good estimate of the partition coefficient $\left(D_{\mathrm{Sr}}\right)$. Using this relationship, theoretical $\mathrm{Sr}: \mathrm{Ca}$ signatures of 'resident' fish from each sector were established (Figure $5 \mathrm{~b}$ ). There was also a positive relationship between $\mathrm{Ba}: \mathrm{Ca}$ in water and in otoliths $\left(y=0.0209 x-2.98, R^{2}=0.93, P=0.025\right.$; Figure $5 \mathrm{c}$ ) confirming the potential of $\mathrm{Ba}: \mathrm{Ca}$ for station discrimination.

Moreover, there was a significant difference in $D_{\mathrm{Ba} \text { :Ca }}$ values between the Ardèche and the other sectors (Figure $5 \mathrm{~d}$ ). As a result, 
(a)

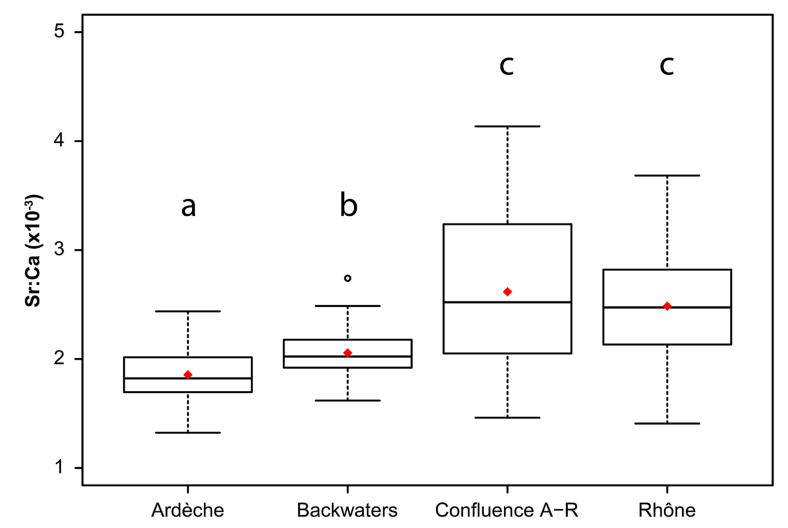

(b)

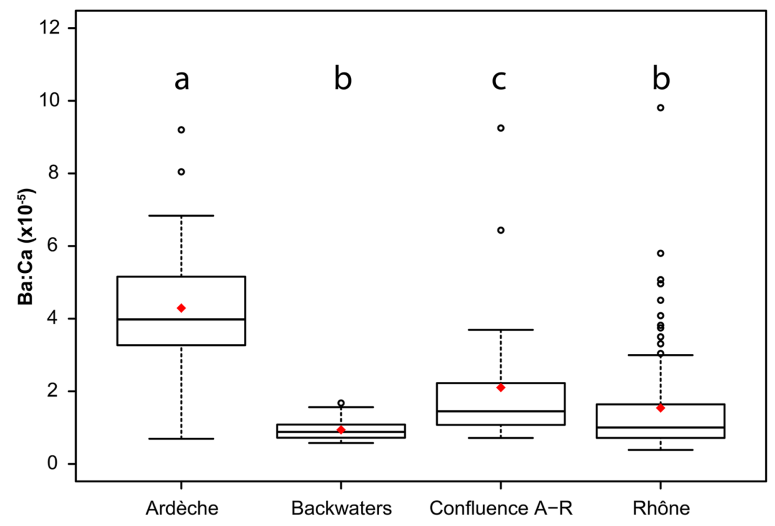

(c)

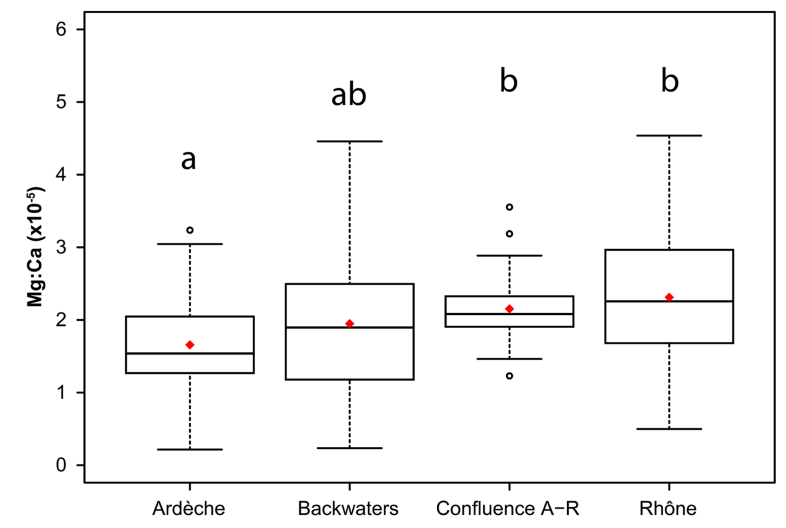

FIGURE 4 Boxplots of elemental ratios of (a) Sr:Ca, (b) Ba:Ca and (c) Mg:Ca of the otolith edge of chub sampled from the different sectors. The red dot represents the mean. Letters above the boxplots $(a, b, c)$ indicate differences between stations $(P<0.05)$ determined with a Wilcoxon rank-sum test. Confluence A-R, confluence between the Ardèche and River Rhône

the Ba:Ca signature was used successfully to discriminate fish from the Ardèche. There was no significant correlation, however, between Mg:Ca signatures in water and otoliths $(r(113)=0.17, P=0.077)$, so this element was removed from further analysis. As a result, only $\mathrm{Sr}$ : $\mathrm{Ca}$ and $\mathrm{Ba}: \mathrm{Ca}$ signatures were combined to identify the origin (spawning area) of fish and their migration patterns.

\section{4 | Microchemical characterization of YOY natal origin}

Given the acquired elemental signatures from the water and otoliths, three potential spawning areas were considered: the Rhône, the Ardèche and the backwaters. Among the 178 juveniles studied, natal origins were identified for 168 of them (94.3\%), allowing further migration analyses. Overall, $66.3 \%$ of the fish seemed to have originated from their sampling station. Fish sampled in the Rhône (stations C, D, E, F and G) originated from the Rhône itself (51.7\%), the backwaters (31.9\%) and the Ardèche (10.4\%). In the downstream station (G), $41.2 \%$ of fish had a typical microchemical profile from the backwaters, $29.4 \%$ from the Ardèche and only $17.6 \%$ from the Rhône. Although a few fish sampled in the backwaters seemed to be from the
Rhône (6.5\%), the vast majority of fish sampled in the Ardèche (96.8\%) and the backwaters (90.3\%) were natives of their sampling stations (Figure 6).

\section{5 | Attempt in reconstructing YOY life-history}

\subsubsection{Fish hatched in the Ardèche}

Of the 42 fish hatched in the Ardèche, 12 exhibited a significant change (split) in the chemical signature. Five of them were captured in the confluence (station F) suggesting a downstream migration from the Ardèche to the Rhône that occurred between mid-August and mid-September (fish of $60 \pm 12 \mathrm{dph}$ ). However, seven of the fish whose profile exhibited a change in the chemical signature were captured in their hatching area (the Ardèche) suggesting that they did not migrate owing to the presence of a weir, and that the variation in the elemental profile could be due to water properties. Indeed, these changes corresponded to an increase in $\mathrm{Sr}: \mathrm{Ca}$ and $\mathrm{Ba}: \mathrm{Ca}$ signatures that occurred from early October to late November, coinciding with the water variation at that time (Figure S2a, b), although the change in Sr:Ca recorded in the water was not as pronounced. 
(a)

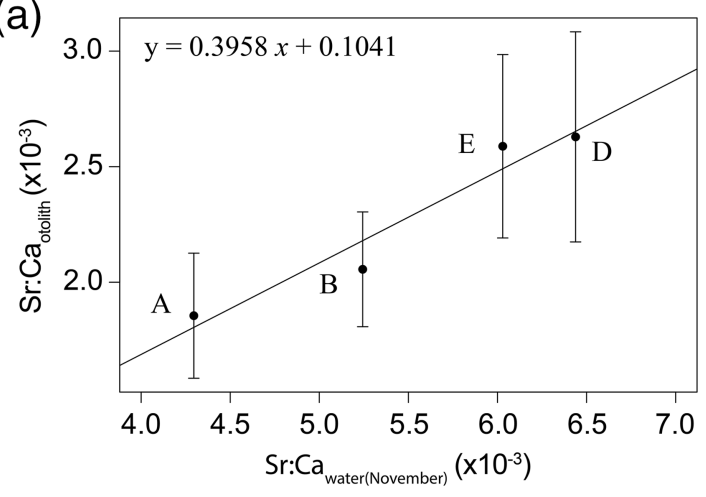

(c)

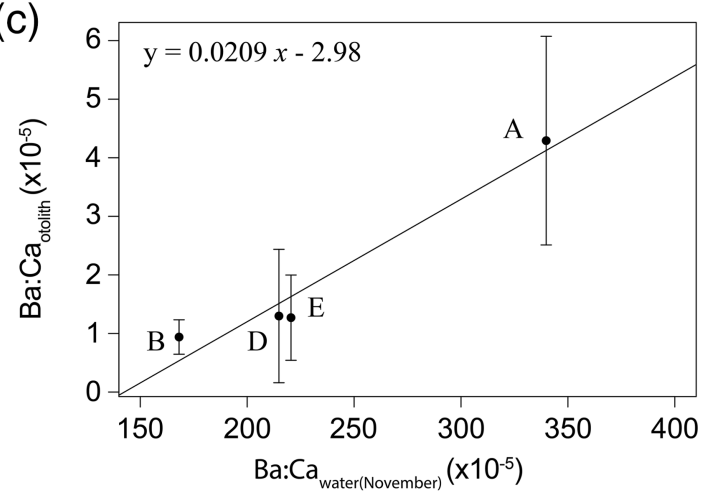

(b)

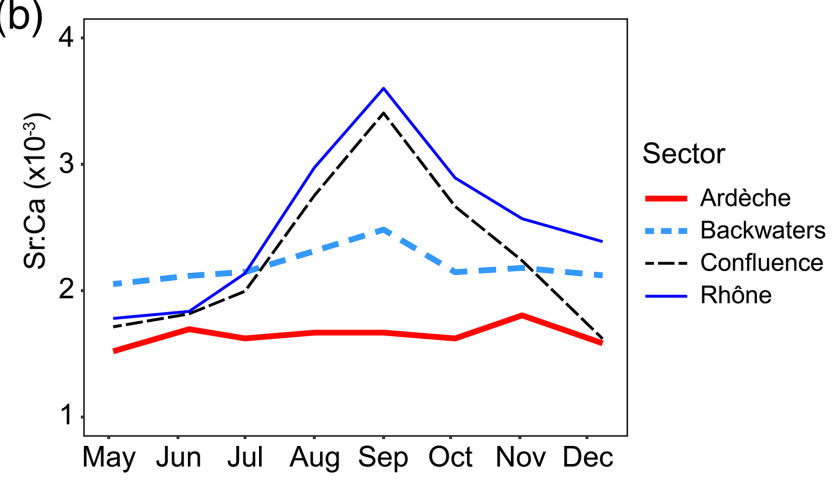

(d)

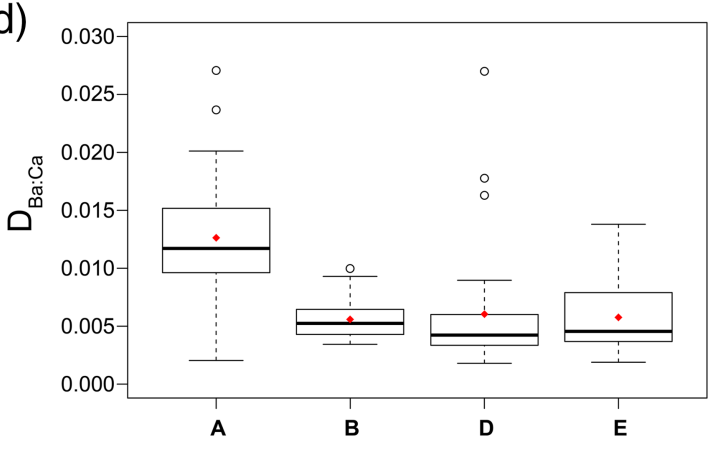

FIGURE 5 Linear regression between elemental ratios recorded in water samples and otolith edge of Squalius cephalus. The relationship for the elemental ratios of (a) Sr:Ca and (c) Ba:Ca was calculated for stations A, B, E and D. (b) Theoretical Sr:Ca signatures for each month for nonmigratory fish from each sector: Ardèche (red), backwaters (light blue), Rhône (blue) and the confluence between the Ardèche and the Rhône (black). (d) Partition coefficients of elemental ratio $D_{\mathrm{Ba}: \mathrm{Ca}}$ in stations $\mathrm{A}, \mathrm{B}, \mathrm{E}$ and $\mathrm{D}$. A, Ardèche; $\mathrm{B}$, backwaters; E, Rhône (downstream from the backwaters); D, Rhône (upstream from the backwaters)

Moreover, among the 30 fish that did not show a change in their elemental profile, seven were not recaptured in the Ardèche but in the confluence (station $\mathrm{F}, \mathrm{N}=3$ ) and downstream (station $\mathrm{G}, \mathrm{N}=4$ ), suggesting a late migration to these stations. These late migrations may have been provoked by the Ardèche flood that occurred in late November (Figure S1) and did not have time to be integrated into the otolith chemistry.

\subsubsection{Fish hatched in the backwaters}

Of the 64 fish hatched in the backwaters, 15 profiles exhibited a significant change (split) in the chemical signature, all coinciding with a migration from the Rhône: to the by-passed section (station $D$, $\mathrm{N}=3$ - station $\mathrm{E}, \mathrm{N}=7$ - station $\mathrm{F}, \mathrm{N}=1$ ) and downstream (station $\mathrm{G}, \mathrm{N}=4$ ), suggesting some possible upstream migrations but a majority of downstream migrations. Furthermore, among the fish that did not show a change in their elemental profile, 21 were not recaptured in the backwaters but in the Rhône (station $D, N=6$ station $\mathrm{E}, \mathrm{N}=9$ - station $\mathrm{F}, \mathrm{N}=3$ - station $\mathrm{G}, \mathrm{N}=3$ ), suggesting late migrations. This could be due to the fact that the elemental signatures of $\mathrm{Sr}: \mathrm{Ca}$ and $\mathrm{Ba}: \mathrm{Ca}$ between the backwaters and the Rhône were difficult to discriminate from November onwards.

\subsection{3 | Fish hatched in the River Rhône}

Of the 62 fish hatched in the Rhône, 28 profiles exhibited no change in the chemical signature with high $\mathrm{Sr}: \mathrm{Ca}$ and low $\mathrm{Ba}: \mathrm{Ca}$ values whereas 34 profiles showed a change. Among the fish whose profile exhibited a change in the chemical signature, 32 were recaptured in the Rhône suggesting the change was the result of the temporal Sr:Ca variations in the Rhône, and two were captured in the backwaters, suggesting migrations from the Rhône to the backwaters.

\subsection{4 | Timing of migrations}

Overall, 51 (30.4\%) fish migrated from one station to another: 12 (7.1\%) from the Ardèche to the Rhône, 36 (21.4\%) from the backwaters to the Rhône, two (1.2\%) from the Rhône to the backwaters; and one fish that hatched in the Rhône migrated to the backwaters and was captured back in the Rhône.

Concerning fish with an elemental profile that exhibited a significant change (split) in the chemical signature, migrations from the Ardèche to the Rhône occurred between mid-August and mid-September (fish of $60 \pm 12 \mathrm{dph}$ ). Migrations from the 
FIGURE 6 Proportion of fish originating from each sector for all sampled stations: Ardèche (red), backwaters (light blue), Rhône (blue) and undetermined origins (grey)

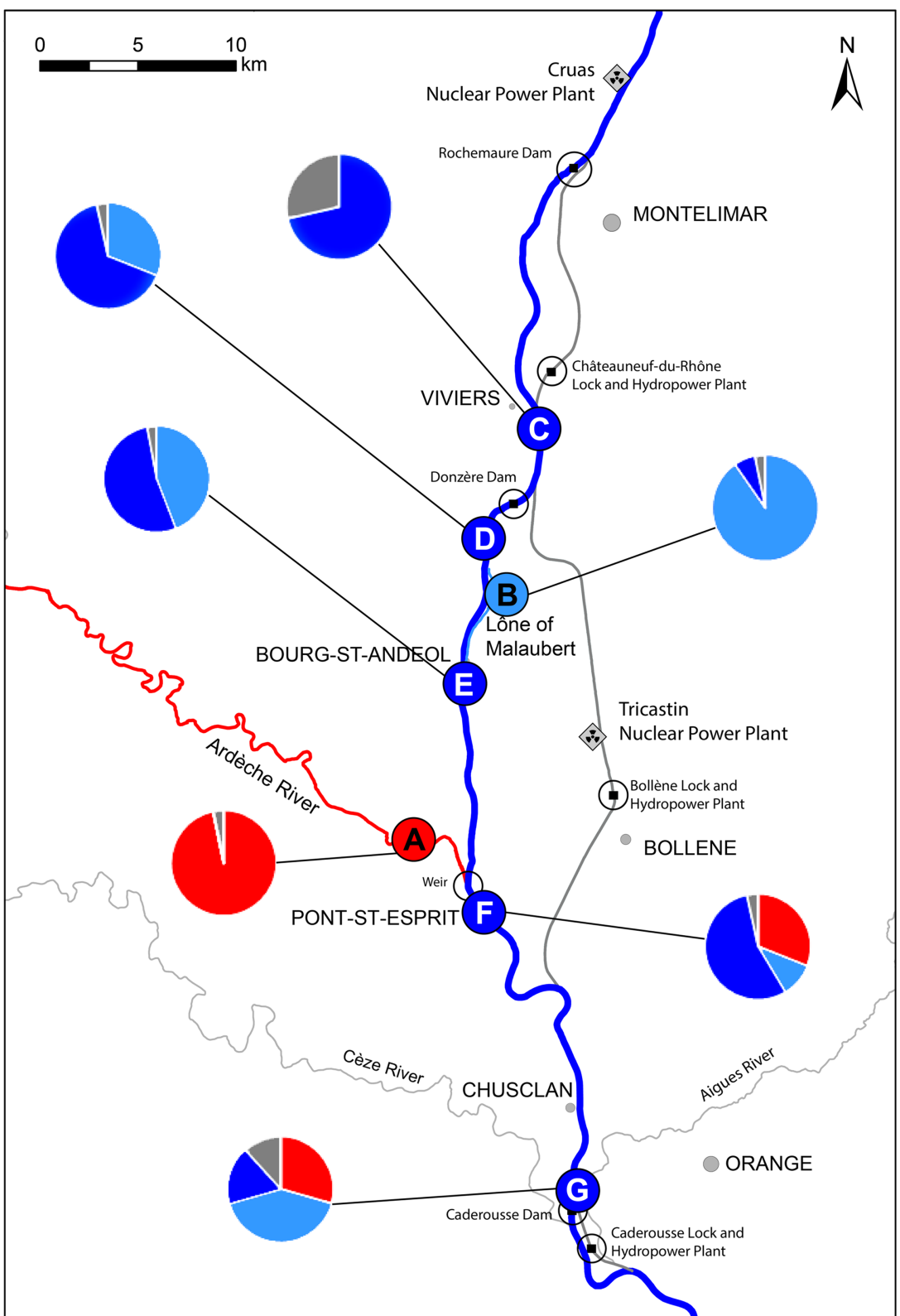

backwaters to the Rhône mostly occurred from mid-September to early November (fish were $59 \pm 22 \mathrm{dph}$ ), except for two individuals that migrated in July (12 and $16 \mathrm{dph}$ ). On average, the migration occurred 51 ( \pm 24) days after hatching. However, five individuals moving between the backwaters and the Rhône were particularly young at the time of migration (only 12-25 dph).

\section{DISCUSSION}

The use of trace elements is an effective tool in determining both the primary recruitment sources and the habitats for early life stages for the European chub, and most likely other cyprinids. The potential rehabilitation of tributaries along the river could provide the ideal nursery habitat needed for YOY fishes, leading to an increase in hatching production, which could benefit local and more distant populations. The purpose of this study was to assess the spawning areas and habitat use of YOY chub via otolith microchemistry. The information obtained from this study will greatly enhance knowledge of European chub origins and dispersal habits. Understanding how these habitats are connected is essential for successful conservation and focusing on specific locations that can be protected to enhance conservation goals (Pracheil et al., 2014). This research demonstrates the utility of otolith microchemistry to identify site-specific natal contributions and provides further information that can be used for habitat protection and restoration. 


\subsection{Are the water properties in the study area suited to the use of otolith microchemistry for habitat use reconstruction?}

The use of otolith microchemistry to identify accurately the natal origin and reconstruct migration history requires the existence of chemically distinct habitats and the stability in time of the chemical signature within these habitats (Gillanders, 2002).

Whereas the water chemical signature of $\mathrm{Ba}: \mathrm{Ca}$ allowed a distinction between the Ardèche and the other sectors throughout the year, this was not the case for Sr:Ca signatures. Indeed, the water chemical signature of Sr:Ca was not stable in all of the habitats studied, which in turn led to the different sectors not being distinct for some parts of the year. Whereas the strontium signature was relatively stable in the Ardèche and the backwaters, it was highly variable in the Rhône, showing habitat-specific variability. These water properties resulted in spatial discrimination being accurate only from August to October. Although differences in water chemical signatures between locations can sometimes be explained by geomorphology (Hegg, Kennedy \& Fremier, 2013), temporal variations in the elemental signatures are generally not well understood and certainly not accurately predictable (Brennan et al., 2015). As suggested by Gillanders (2002), the use of otolith microchemistry as a tool for reconstructing the environmental history of fish requires constituting a library of elemental fingerprints over several seasons or years, depending on the scales of the studies to obtain the most accurate interpretations.

These issues of temporal variability were remedied by converting the elemental signature of otoliths to the corresponding calendar date. By using this method, it was assumed that changes in the otolith elemental signal resulting from changes in elemental signatures of water were not significantly delayed in time.

\section{2 | Use of otolith microchemistry to discriminate the River Rhône, its tributaries and backwaters}

In this study, strontium followed by barium were the most useful marker elements to study the origin and migrations of juvenile coarse fishes. The relevance of these elements has already been reported in several other studies (Wells et al., 2003; Elsdon \& Gillanders, 2003b; Fukushima et al., 2014). Indeed, non-essential elements such as these act as a calcium mimic, so are often incorporated into biological matrices in place of calcium through their uptake mechanisms (Loewen et al., 2016) and reflect the environmental composition in calcium-based structures such as otoliths (Campana, 1999).

Examination of otolith $\mathrm{Sr}: \mathrm{Ca}$ signatures of fishes within freshwater systems allows assessments of habitat shift at micro-scales (Muhlfeld et al., 2012; Teichert et al., 2018) owing to groundwater hydrology and underlying geological conditions leading to local environmental strontium isotopic ratios that are reflected in otolith composition (Hegg, Kennedy \& Fremier, 2013; Brennan et al., 2015). The strontium partition coefficient in S. cephalus otoliths $(0.396)$ was similar to those observed for the cyprinids Henicorhynchus siamensis
(0.409) and Henicorhynchus lobatus (0.496) (Fukushima et al., 2014), and other families of freshwater species such as the salmonid Oncorhynchus clarki lewisi (0.40) (Wells et al., 2003).

The barium partition coefficients in the otoliths of the juveniles sampled in the Rhône and the backwaters were very low compared with those of the cyprinid genus Henicorhynchus (Fukushima et al., 2014) and other fish species such as the cutthroat trout (Wells et al., 2003) or the black bream (Elsdon \& Gillanders, 2003b; Elsdon \& Gillanders, 2005b). Studies tend to show a considerable variation in Ba partition coefficients between species (Melancon, Fryer \& Markham, 2009) but also within the same species depending on environmental conditions such as temperature (Bath et al., 2000; Elsdon \& Gillanders, 2003b; Elsdon \& Gillanders, 2005b) owing to physiological control over element fractionation and partitioning (Sturrock et al., 2014; Sturrock et al., 2015). This seemed to be the case in this study too, with about a 2-fold difference between the Ardèche Ba partition coefficients (0.013) and those found in the other sectors (0.0057).

Although some differences in the $\mathrm{Mg}: \mathrm{Ca}$ water signatures could be detected between stations (especially between the backwaters and the others), there were no significant differences in the $\mathrm{Mg}: \mathrm{Ca}$ signatures of lapilli otoliths, showing magnesium to be a very ineffective marker for $S$. cephalus. Unlike strontium and barium that are non-essential life elements, magnesium is involved in numerous physiological mechanisms, and its concentration in the organism is governed by its own regulatory processes (Woodcock et al., 2012). This could explain why there was no correlation between water and otolith $\mathrm{Mg}$ :Ca ratios in the study presented here, confirming previous results (Fukushima et al., 2014; Teichert et al., 2018).

The results showed that simultaneously using strontium and barium water signatures successfully discriminated geographical locations of fish even in a small-scale system, and confirm the value of using otoliths to reconstruct fish migration in freshwater environments (Wells et al., 2003; Muhlfeld et al., 2012). These elements have been used in many studies to provide evidence of essential habitat to fish life cycles. For example, they were used to determine the natal origin of anadromous fish such as the Atlantic salmon Salmo salar (Kennedy et al., 2000; Martin et al., 2013) and shad Alosa alosa and Alosa fallax (Nachón et al., 2020) to evaluate recruitment and stock contributions. Otolith microchemistry was also used to determine the habitat of the early life stage of the amphidromous goby Sicyopterus lagocephalus (Teichert et al., 2018), the bighead carp Hypophthalmichthys nobilis and the silver carp Hypophthalmichthys molitrix, both invasive species in North America (Whitledge et al., 2019).

\subsection{Fish natal origin and patterns of migration/ dispersal}

Otolith microchemistry provided evidence that the three sectors studied were all population sources of the Rhône. Indeed, elemental fingerprints of the otoliths showed that adult reproduction in the Ardèche tributary and in the backwaters can sustain the Rhône population(s) of chub, but that the spawning habitats in the main River 
Rhône provided more than half of its own populations. Conversely, the Rhône populations seemed unable to migrate in support of the tributary and backwater populations. Juvenile chub were probably able to drift longitudinally along the main River Rhône for several kilometres. Indeed, the fact that individuals that hatched in the tributary and the backwaters were sampled in the downstream reservoir, separated by several kilometres $(20-30 \mathrm{~km})$, suggests that, despite their small size, some early life stages of $S$. cephalus could drift between spawning and nursery areas quite early in their development. Although the weir at the confluence of the Ardèche and the Rhône has been improved for adult species migration, it does not appear suitable for the upstream dispersal of juveniles, in particular during periods of instream flow in the by-passed Rhône section. These results show the importance of connectivity between the main channel and its annexes (tributaries, side channels, backwaters) for fish recruitment and population maintenance as mentioned by other studies on the effect of river regulation (Copp, 1990). In addition, most migrations seem to be linked to downstream drift of YOY fish as observed in previous studies (Sonny et al., 2006; Reichard \& Jurajda, 2007). However, results from otolith microchemistry showed that the majority of juveniles (70\%) did not spread far away from their hatching area. This can result from an inshore retention of larvae (Schiemer et al., 2001) and from an active component of larval dispersal as shown by Schludermann et al. (2012) in the Danube River.

Fish migrations between sites that were observed through otolith $\mathrm{Sr}: \mathrm{Ca}$ signatures seemed random in time and highly heterogeneous (Figure S3), suggesting complicated dispersal patterns. Further studies would be needed to assess more precisely the influence of habitat characteristics (e.g. current velocity, depth, vegetation), environmental conditions (flood, temperature), as well as food quality and quantity (Gaudin, 2001) on migrations.

\section{4 | Implications for management and restoration}

The effectiveness of otolith microchemistry analysis in identifying the origin and movements of YOY chub makes it a powerful tool for understanding the dynamics of fish populations (evaluation of recruitment and stock contributions). Otolith microchemistry can be used for determining the essential habitats used by fish during their life cycle, leading to adaptive management for the protection of these habitats. In addition to helping with questions concerning connectivity, for instance in the case of invasive fish species, this tool could be useful in determining breeding areas and in targeting management actions accordingly.

In the studied reach of the Rhône, a large regulated river, fish collected in the old river main course originated from tributaries, backwaters and the main river; it was also shown that dispersal occurred mainly from upstream to downstream. The chub 'subpopulations' observed at present in the three reach units have a rather unidirectional pattern of connectivity: from tributaries (or backwaters) towards the main river. For a riverine generalist species, this should not be the case in normally interconnected reach units. Indeed, a study of the colonization and succession of the fish community in a reconnected floodplain of the Upper Danube river has shown that the chub was among the first species to arrive, and a fast responding species after reconnection of the backwaters (Pander, Mueller \& Geist, 2015). As the reach of Caderousse is representative of hydroelectric facilities along the River Rhône, the pattern of connectivity observed here could be similar in other regulated reaches of the river (Olivier et al., 2009) that are currently being rehabilitated (Riquier et al., 2017). The patterns observed may also be representative of other large regulated floodplain rivers in Europe (e.g. the River Rhine or the River Danube) and elsewhere in the world (Tockner, Uehlinger \& Robinson, 2009). In the light of the major challenges of floodplain rehabilitation and cost-effective objectives (Schmutz et al., 2014; Lamouroux et al., 2015; Erős et al., 2019), this study proposes the use of new tools to assess the success of restoration projects.

Most large rivers are colonized by invasive fish species such as silver carp and bighead carp in North America (Upper Mississippi and Illinois River, for example), Pseudorasbora parva in the River Rhône, common carp Cyprinus carpio in Australia, and round goby Neogobius melanostomus in the Rhine. Whitledge et al. (2019) showed that otolith microchemistry was able to determine the habitat requirements for invasive fish species. Using this knowledge could be helpful in developing specific actions to regulate these species (such as the control of reproduction, upstream recruitment and immigration from downstream). This study showed that the trace elemental signatures in water and otoliths were able to distinguish the habitat used by fish at a relatively small scale (several kilometres) in a large river. The application of the microchemistry approach to invasive species will lead to a better understanding of their life cycle and favour a more rigorous management by acting specifically on early or essential life stages of fish life cycles. Moreover, otolith microchemistry (and particularly the composition in $\mathrm{Sr}$ and $\mathrm{Ba}$ ) has been used in some studies to evaluate the date and the sources of illegal introduction (Munro, McMahon \& Ruzycki, 2005) and to evaluate the impact of escaped farm fish as suggested by de Braux et al. (2014) on Atlantic salmon.

\section{5 | Methodological advances}

In most of the studies, otolith microchemistry has been used to elucidate the life histories of large migratory fishes such as anadromous or catadromous species, whereas in this study it was shown that otolith microchemistry could be used for studying inland freshwater fishes that perform small-scale migrations of only a few kilometres in rivers. In many studies, elemental signatures are given as a function of distances on the otolith without taking into account the variation in growth rates, making it difficult to interpret migrations over time. In this study, the combination of daily growth rates and otolith microchemistry was a powerful tool to study the timing of migration and to link migrations to environmental events such as floods. These results can now be used to study fish spawning events 
more precisely as well as fish growth over time, thereby contributing to a growing field of research using otolith microchemistry to investigate fish life history.

Following long-term extensive regulation of large rivers, an increasing interest in ecological rehabilitation led to ambitious projects to improve hydrological connectivity and to mitigate hydromorphological alterations. The connectivity patterns observed in the River Rhône for the chub do not conform to the general pattern for fish. However, other species such as roach (Hohausova, Copp \& Jankovskỳ, 2003; Pollux et al., 2006) or the common nase (De Leeuw \& Winter, 2008) as well as other potamodromous species that are able to use backwaters and tributaries for reproduction may present similar patterns of connectivity. In this regard, further studies on natal origin and migration of early life stages of fish could help assess the success or failure of rehabilitation programmes (Bolland et al., 2012; Lorenz et al., 2013).

These findings would have been practically impossible to achieve using alternative methods, highlighting otolith microchemistry as a prime tool for management and conservation (Pracheil et al., 2014) and promoting its more widespread use.

\section{ACKNOWLEDGEMENTS}

The authors would like to thank everyone involved in fish sampling and data collection, in particular Virginie Diouloufet. Many thanks as well to everyone at the IPREM laboratory involved with the equipment setup, and to the Compagnie Nationale du Rhône that provided water discharge data. This study was funded by the French Office for Biodiversity (OFB), by Electricity of France (EDF), and by the French National Research Institute for Agriculture, Food and Environment (INRAE). The authors would also like to thank $\mathrm{Dr}$ Matthew O'Hare as well as two anonymous referees for their helpful comments and suggestions. The authors also thank Coralie Garron for proofreading the last version of this manuscript.

\section{CONFLICT OF INTEREST}

The authors declare that there is no conflict of interest regarding the publication of this article.

\section{DATA AVAILABILITY STATEMENT}

The data that support the findings of this study are available on request from the corresponding author. The data are not publicly available owing to privacy restrictions.

\section{ORCID}

Bernadette Bounket (D) https://orcid.org/0000-0002-2388-6540

\section{REFERENCES}

Arthington, A.H., Dulvy, N.K., Gladstone, W. \& Winfield, I.J. (2016). Fish conservation in freshwater and marine realms: Status, threats and management. Aquatic Conservation: Marine and Freshwater Ecosystems, 26(5), 838-857. https://doi.org/10.1002/aqc.2712

Bacalbasa-Dobrovici, N. (1997). Endangered migratory sturgeons of the lower Danube River and its delta. Environmental Biology of Fishes, 1(48), 201-207. https://doi.org/10.1007/0-306-46854-9_10
Bath, G.E., Thorrold, S.R., Jones, C.M., Campana, S.E., McLaren, J.W. \& Lam, J.W.H. (2000). Strontium and barium uptake in aragonitic otoliths of marine fish. Geochimica et Cosmochimica Acta, 64(10), 1705-1714. https://doi.org/10.1016/S0016-7037(99)00419-6

Beger, M., Grantham, H.S., Pressey, R.L., Wilson, K.A., Peterson, E.L., Dorfman, D. et al. (2010). Conservation planning for connectivity across marine, freshwater, and terrestrial realms. Biological Conservation, 143(3), 565-575. https://doi.org/10.1016/j.biocon.2009.11.006

Benitez, J.-P., Nzau Matondo, B., Dierckx, A. \& Ovidio, M. (2015). An overview of potamodromous fish upstream movements in mediumsized rivers, by means of fish passes monitoring. Aquatic Ecology, 49(4), 481-497. https://doi.org/10.1007/s10452-015-9541-4

Bernhardt, E.S., Sudduth, E.B., Palmer, M.A., Allan, J.D., Meyer, J.L., Alexander, G. et al. (2007). Restoring rivers one reach at a time: Results from a survey of US river restoration practitioners. Restoration Ecology, 15(3), 482-493. https://doi.org/10.1111/j.1526-100X.2007.00244.x

Bierschenk, A.M., Mueller, M., Pander, J. \& Geist, J. (2019). Impact of catchment land use on fish community composition in the headwater areas of Elbe, Danube and Main. Science of the Total Environment, 652, 66-74. https://doi.org/10.1016/j.scitotenv.2018.10.218

Bolland, J.D., Nunn, A.D., Lucas, M.C. \& Cowx, I.G. (2012). The importance of variable lateral connectivity between artificial floodplain waterbodies and river channels. River Research and Applications, 28(8), 1189-1199. https://doi.org/10.1002/rra.1498

Bounket, B., Gibert, P., Gennotte, V., Argillier, C., Carrel, G., Maire, A. et al. (2019). Otolith shape analysis and daily increment validation during ontogeny of larval and juvenile European chub Squalius cephalus. Journal of Fish Biology, 95(2), 444-452. https://doi.org/10.1111/jfb.13976

Brennan, S.R., Fernandez, D.P., Zimmerman, C.E., Cerling, T.E., Brown, R.J. \& Wooller, M.J. (2015). Strontium isotopes in otoliths of a nonmigratory fish (slimy sculpin): Implications for provenance studies. Geochimica et Cosmochimica Acta, 149, 32-45. https://doi.org/10. 1016/j.gca.2014.10.032

Brown, A.G., Lespez, L., Sear, D.A., Macaire, J.-J., Houben, P., Klimek, K. et al. (2018). Natural vs anthropogenic streams in Europe: History, ecology and implications for restoration, river-rewilding and riverine ecosystem services. Earth-Science Reviews, 180, 185-205. https://doi. org/10.1016/j.earscirev.2018.02.001

Bunn, S.E. \& Arthington, A.H. (2002). Basic principles and ecological consequences of altered flow regimes for aquatic biodiversity. Environmental Management, 30(4), 492-507. https://doi.org/10.1007/ s00267-002-2737-0

Campana, S.E. (1999). Chemistry and composition of fish otoliths: Pathways, mechanisms and applications. Marine Ecology Progress Series, 188, 263-297. https://doi.org/10.3354/meps188263

Campana, S.E. (2001). Accuracy, precision and quality control in age determination, including a review of the use and abuse of age validation methods. Journal of Fish Biology, 59(2), 197-242. https://doi.org/10.1111/j.1095-8649.2001.tb00127.x

Campana, S.E. \& Neilson, J.D. (1985). Microstructure of fish otoliths. Canadian Journal of Fisheries and Aquatic Sciences, 42(5), 1014-1032. https://doi.org/10.1139/f85-127

Campana, S.E. \& Thorrold, S.R. (2001). Otoliths, increments, and elements: Keys to a comprehensive understanding of fish populations? Canadian Journal of Fisheries and Aquatic Sciences, 58(1), 30-38. https://doi.org/ 10.1139/f00-177

Capra, H., Pella, H. \& Ovidio, M. (2018). Individual movements, home ranges and habitat use by native rheophilic cyprinids and non-native catfish in a large regulated river. Fisheries Management and Ecology, 25(2), 136-149. https://doi.org/10.1111/fme.12272

Copp, G.H. (1990). Effect of regulation on 0+ fish recruitment in the Great Ouse, a lowland river. Regulated Rivers: Research \& Management, 5(3), 251-263. https://doi.org/10.1002/rrr.3450050306

Daverat, F., Tomas, J., Lahaye, M., Palmer, M. \& Elie, P. (2005). Tracking continental habitat shifts of eels using otolith Sr/Ca ratios: Validation 
and application to the coastal, estuarine and riverine eels of the Gironde-Garonne-Dordogne watershed. Marine and Freshwater Research, 56(5), 619-627. https://doi.org/10.1071/MF04175

de Braux, E., Warren-Myers, F., Dempster, T., Fjelldal, P.G., Hansen, T. \& Swearer, S.E. (2014). Osmotic induction improves batch marking of larval fish otoliths with enriched stable isotopes. ICES Journal of Marine Science, 71(9), 2530-2538. https://doi.org/10.1093/icesjms/ fsu091

De Leeuw, J.J. \& Winter, H.V. (2008). Migration of rheophilic fish in the large lowland rivers Meuse and Rhine, the Netherlands. Fisheries Management and Ecology, 15(5-6), 409-415. https://doi.org/10.1111/ j.1365-2400.2008.00626.x

Dudgeon, D., Arthington, A.H., Gessner, M.O., Kawabata, Z.-I., Knowler, D.J., Lévêque, C. et al. (2006). Freshwater biodiversity: Importance, threats, status and conservation challenges. Biological Reviews, 81(2), 163-182. https://doi.org/10.1017/S1464793105006950

Egan, E.M.C., Hickford, M.J.H. \& Schiel, D.R. (2019). Understanding the life histories of amphidromous fish by integrating otolith-derived growth reconstructions, post-larval migrations and reproductive traits. Aquatic Conservation: Marine and Freshwater Ecosystems, 29(9), 1391-1402. https://doi.org/10.1002/aqc.3145

Elsdon, T.S. \& Gillanders, B.M. (2003a). Reconstructing migratory patterns of fish based on environmental influences on otolith chemistry. Reviews in Fish Biology and Fisheries, 13(3), 217-235. https://doi.org/ 10.1023/B:RFBF.0000033071.73952.40

Elsdon, T.S. \& Gillanders, B.M. (2003b). Relationship between water and otolith elemental concentrations in juvenile black bream Acanthopagrus butcheri. Marine Ecology Progress Series, 260, 263-272. https://doi.org/10.3354/meps260263

Elsdon, T.S. \& Gillanders, B.M. (2004). Fish otolith chemistry influenced by exposure to multiple environmental variables. Journal of Experimental Marine Biology and Ecology, 313(2), 269-284. https://doi.org/10. 1016/j.jembe.2004.08.010

Elsdon, T.S. \& Gillanders, B.M. (2005a). Strontium incorporation into calcified structures: Separating the effects of ambient water concentration and exposure time. Marine Ecology Progress Series, 285, 233-243. https://doi.org/10.3354/meps285233

Elsdon, T.S. \& Gillanders, B.M. (2005b). Consistency of patterns between laboratory experiments and field collected fish in otolith chemistry: An example and applications for salinity reconstructions. Marine and Freshwater Research, 56(5), 609-617. https://doi.org/10.1071/MF04146

Elsdon, T.S., Wells, B.K., Campana, S.E., Gillanders, B.M., Jones, C.M., Limburg, K.E. et al. (2008). Otolith chemistry to describe movements and life-history parameters of fishes: Hypotheses, assumptions, limitations and inferences. Oceanography and Marine Biology: An Annual Review, 46, 297-330.

Erős, T., Kuehne, L., Dolezsai, A., Sommerwerk, N. \& Wolter, C. (2019). A systematic review of assessment and conservation management in large floodplain rivers - Actions postponed. Ecological Indicators, 98, 453-461. https://doi.org/10.1016/j.ecolind.2018.11.026

Espinoza, M., Lédée, E.J.I., Simpfendorfer, C.A., Tobin, A.J. \& Heupel, M.R. (2017). Contrasting movements and connectivity of reef-associated sharks using acoustic telemetry: Implications for management. Ecological Applications, 25(8), 2101-2118. https://doi.org/10.1890/14-2293.1

Faulks, L.K., Gilligan, D.M. \& Beheregaray, L.B. (2011). The role of anthropogenic vs. natural in-stream structures in determining connectivity and genetic diversity in an endangered freshwater fish, Macquarie perch (Macquaria australasica). Evolutionary Applications, 4(4), 589-601. https://doi.org/10.1111/j.1752-4571.2011.00183.x

Feunteun, E. (2002). Management and restoration of European eel population (Anguilla anguilla): An impossible bargain. Ecological Engineering, 18(5), 575-591. https://doi.org/10.1016/S0925-8574(02) 00021-6

Fredrich, F., Ohmann, S., Curio, B. \& Kirschbaum, F. (2003). Spawning migrations of the chub in the River Spree, Germany. Journal of Fish
Biology, 63(3), 710-723. https://doi.org/10.1046/j.1095-8649.2003. 00184.x

Fukushima, M., Jutagate, T., Grudpan, C., Phomikong, P. \& Nohara, S. (2014). Potential effects of hydroelectric dam development in the Mekong River Basin on the migration of Siamese mud carp (Henicorhynchus siamensis and $H$. lobatus) elucidated by otolith microchemistry. PLoS ONE, 9(8), e103722. https://doi.org/10.1371/ journal.pone.0103722

Fullerton, A.H., Burnett, K.M., Steel, E.A., Flitcroft, R.L., Pess, G.R., Feist, B.E. et al. (2010). Hydrological connectivity for riverine fish: Measurement challenges and research opportunities. Freshwater Biology, 55(11), 2215-2237. https://doi.org/10.1111/j.1365-2427. 2010.02448.x

Gaudin, P. (2001). Habitat shifts in juvenile riverine fishes. Archiv für Hydrobiologie. Supplementband. Large Rivers, 12(2-4), 393-408. https://doi.org/10.1127//r/12/2001/393

Gido, K.B., Whitney, J.E., Perkin, J.S. \& Turner, T.F. (2016). Fragmentation, connectivity and fish species persistence in freshwater ecosystems. In: G.P. Closs, M. Krkosek, J.D. Olden (Eds.) Conservation of freshwater fishes. Cambridge: Cambridge University Press, pp. 292-323.

Gillanders, B.M. (2002). Temporal and spatial variability in elemental composition of otoliths: Implications for determining stock identity and connectivity of populations. Canadian Journal of Fisheries and Aquatic Sciences, 59(4), 669-679. https://doi.org/10.1139/f02-040

Gouskov, A., Reyes, M., Wirthner-Bitterlin, L. \& Vorburger, C. (2016). Fish population genetic structure shaped by hydroelectric power plants in the upper Rhine catchment. Evolutionary Applications, 9(2), 394-408. https://doi.org/10.1111/eva.12339

Haidvogl, G., Hoffmann, R., Pont, D., Jungwirth, M. \& Winiwarter, V. (2015). Historical ecology of riverine fish in Europe. Aquatic Sciences, 77, 315-324. https://doi.org/10.1007/s00027-015-0400-0

Hall, C.J., Jordaan, A. \& Frisk, M.G. (2011). The historic influence of dams on diadromous fish habitat with a focus on river herring and hydrologic longitudinal connectivity. Landscape Ecology, 26(1), 95-107. https://doi.org/10.1007/s10980-010-9539-1

Hegg, J.C., Kennedy, B.P. \& Fremier, A.K. (2013). Predicting strontium isotope variation and fish location with bedrock geology: Understanding the effects of geologic heterogeneity. Chemical Geology, 360-361, 89-98. https://doi.org/10.1016/j.chemgeo.2013. 10.010

Hickford, M.J.H. \& Schiel, D.R. (2014). Experimental rehabilitation of degraded spawning habitat of a diadromous fish, Galaxias maculatus (Jenyns, 1842) in rural and urban streams. Restoration Ecology, 22(3), 319-326. https://doi.org/10.1111/rec.12079

Hoffmann, R.C. (2005). A brief history of aquatic resource use in medieval Europe. Helgoland Marine Research, 59(1), 22. https://doi.org/10. 1007/s10152-004-0203-5

Hohausova, E., Copp, G.H. \& Jankovskỳ, P. (2003). Movement of fish between a river and its backwater: Diel activity and relation to environmental gradients. Ecology of Freshwater Fish, 12(2), 107-117. https://doi.org/10.1034/j.1600-0633.2003.00014.x

Jansson, R., Nilsson, C. \& Malmqvist, B. (2007). Restoring freshwater ecosystems in riverine landscapes: The roles of connectivity and recovery processes. Freshwater Biology, 52(4), 589-596. https://doi. org/10.1111/j.1365-2427.2007.01737.x

Kalish, J.M. (1989). Otolith microchemistry: Validation of the effects of physiology, age and environment on otolith composition. Journal of Experimental Marine Biology and Ecology, 132(3), 151-178. https://doi. org/10.1016/0022-0981(89)90126-3

Keith, P., Persat, H., Feunteun, É. \& Allardi, J. (2011). Les poissons d'eau douce de France. Paris: Biotope; Museum National d'histoire Naturelle.

Kennedy, B.P., Blum, J.D., Folt, C.L. \& Nislow, K.H. (2000). Using natural strontium isotopic signatures as fish markers: Methodology and application. Canadian Journal of Fisheries and Aquatic Sciences, 57(11), 2280-2292. https://doi.org/10.1139/f00-206 
Kennedy, B.P., Klaue, A., Blum, J.D., Folt, C.L. \& Nislow, K.H. (2002). Reconstructing the lives of fish using $\mathrm{Sr}$ isotopes in otoliths. Canadian Journal of Fisheries and Aquatic Sciences, 59(6), 925-929. https://doi. org/10.1139/f02-070

Kottelat, M. \& Freyhof, J. (2007). Handbook of European freshwater fishes. Switzerland: Publications Kottelat.

Lamouroux, N., Gore, J.A., Lepori, F. \& Statzner, B. (2015). The ecological restoration of large rivers needs science-based, predictive tools meeting public expectations: An overview of the Rhône project. Freshwater Biology, 60(6), 1069-1084. https://doi.org/10.1111/fwb. 12553

Lazartigues, A., Girard, C., Brodeur, P., Lecomte, F., Mingelbier, M. \& Sirois, P. (2018). Otolith microchemistry to identify sources of larval yellow perch in a fluvial lake: An approach towards freshwater fish management. Canadian Journal of Fisheries and Aquatic Sciences, 75(3), 474-487. https://doi.org/10.1139/cjfas-2016-0289

Lechner, A., Keckeis, H., Schludermann, E., Lumesberger-Loisl, F., Humphries, P., Glass, M. et al. (2014). Shoreline configurations affect dispersal patterns of fish larvae in a large river. ICES Journal of Marine Science, 71(4), 930-942. https://doi.org/10.1093/icesjms/fst139

Lenders, H.R. (2017). Fish and fisheries in the Lower Rhine 1550-1950: A historical-ecological perspective. Journal of Environmental Management, 202(Part 2), 403-411. https://doi.org/10.1016/j.jenvman.2016. 09.011

Liermann, C.R., Nilsson, C., Robertson, J. \& Ng, R.Y. (2012). Implications of dam obstruction for global freshwater fish diversity. Bioscience, 62(6), 539-548. https://doi.org/10.1525/bio.2012.62.6.5

Loewen, T.N., Carriere, B., Reist, J.D., Halden, N.M. \& Anderson, W.G. (2016). Linking physiology and biomineralization processes to ecological inferences on the life history of fishes. Comparative Biochemistry and Physiology Part A: Molecular \& Integrative Physiology, 202, 123-140. https://doi.org/10.1016/j.cbpa.2016.06.017

Lorenz, A.W., Stoll, S., Sundermann, A. \& Haase, P. (2013). Do adult and YOY fish benefit from river restoration measures? Ecological Engineering, 61(Part A), 174-181. https://doi.org/10.1016/j.ecoleng. 2013.09.027

Maguffee, A.C., Reilly, R., Clark, R. \& Jones, M.L. (2019). Examining the potential of otolith chemistry to determine natal origins of wild Lake Michigan Chinook salmon. Canadian Journal of Fisheries and Aquatic Sciences, 76(11), 2035-2044. https://doi.org/10.1139/cjfas-2018-0041

Martin, J., Bareille, G., Berail, S., Pecheyran, C., Daverat, F., Bru, N. et al. (2013). Spatial and temporal variations in otolith chemistry and relationships with water chemistry: A useful tool to distinguish Atlantic salmon Salmo salar parr from different natal streams. Journal of Fish Biology, 82(5), 1556-1581. https://doi.org/10.1111/jfb.12089

McDowall, R.M., Allibone, R.M. \& Chadderton, W.L. (2001). Issues for the conservation and management of Falkland Islands freshwater fishes. Aquatic Conservation: Marine and Freshwater Ecosystems, 11(6), 473-486. https://doi.org/10.1002/aqc.499

Melancon, S., Fryer, B.J. \& Markham, J.L. (2009). Chemical analysis of endolymph and the growing otolith: Fractionation of metals in freshwater fish species. Environmental Toxicology and Chemistry, 28(6), 1279. https://doi.org/10.1897/08-358.1

Mellon-Duval, C., de Pontual, H., Métral, L. \& Quemener, L. (2010). Growth of European hake (Merluccius merluccius) in the Gulf of Lions based on conventional tagging. ICES Journal of Marine Science, 67(1), 62-70. https://doi.org/10.1093/icesjms/fsp215

Miller, R.R., Williams, J.D. \& Williams, J.E. (1989). Extinctions of North American fishes during the past century. Fisheries, 14(6), 22-38. https://doi.org/10.1577/1548-8446(1989)014<0022:EONAFD>2.0. $\mathrm{cO} ; 2$

Morse, J.W. \& Bender, M.L. (1990). Partition coefficients in calcite: Examination of factors influencing the validity of experimental results and their application to natural systems. Chemical Geology, 82, 265-277. https://doi.org/10.1016/0009-2541(90)90085-L
Mueller, M., Pander, J. \& Geist, J. (2018). Comprehensive analysis of $>30$ years of data on stream fish population trends and conservation status in Bavaria, Germany. Biological Conservation, 226, 311-320. https://doi.org/10.1016/j.biocon.2018.08.006

Muhlfeld, C.C., Thorrold, S.R., McMahon, T.E. \& Marotz, B. (2012). Estimating westslope cutthroat trout (Oncorhynchus clarkii lewisi) movements in a river network using strontium isoscapes. Canadian Journal of Fisheries and Aquatic Sciences, 69(5), 906-915. https://doi. org/10.1139/f2012-033

Munro, A.R., McMahon, T.E. \& Ruzycki, J.R. (2005). Natural chemical markers identify source and date of introduction of an exotic species: Lake trout (Salvelinus namaycush) in Yellowstone Lake. Canadian Journal of Fisheries and Aquatic Sciences, 62(1), 79-87. https://doi.org/ 10.1139/f04-174

Nachón, D.J., Bareille, G., Drouineau, H., Tabouret, H., Taverny, C., Boisneau, C. et al. (2020). 1980s population-specific compositions of two related anadromous shad species during the oceanic phase determined by microchemistry of archived otoliths. Canadian Journal of Fisheries and Aquatic Sciences, 77(1), 164-176. https://doi.org/10. 1139/cjfas-2018-0444

Olivier, J.-M., Dole-Olivier, M.-J., Amoros, C., Carrel, G., Malard, F., Lamouroux, N. et al. (2009). Chapter 7 - The Rhône River Basin. In: K. Tockner, U. Uehlinger, C.T. Robinson (Eds.) Rivers of Europe. London: Academic Press, pp. 247-295.

Pander, J., Mueller, M. \& Geist, J. (2015). Succession of fish diversity after reconnecting a large floodplain to the upper Danube River. Ecological Engineering, 75, 41-50. https://doi.org/10.1016/j.ecoleng.2014.11.011

Pannella, G. (1971). Fish otoliths: Daily growth layers and periodical patterns. Science, 173(4002), 1124-1127. https://doi.org/10.1126/ science.173.4002.1124

Philippart, J.-C. \& Vranken, M. (1983). Atlas des poissons de Wallonie. Distribution, écologie, éthologie, pêche, conservation. Liège, Belgique: Institut de zoologie de l'Université de Liège.

Piégay, H. (2018). The Rhône River, France: Applying integrative sciences to sustainable management. In: A. Paquier, N. Rivière (Eds.) River Flow 2018 - Ninth International Conference on Fluvial Hydraulics. LyonVilleurbanne, France: E3S web of conferences, 01003.

Planes, S., Jones, G.P. \& Thorrold, S.R. (2009). Larval dispersal connects fish populations in a network of marine protected areas. Proceedings of the National Academy of Sciences, 106(14), 5693-5697. https://doi. org/10.1073/pnas.0808007106

Pollux, B., Korosi, A., Verberk, W., Pollux, P. \& Van der Velde, G. (2006). Reproduction, growth, and migration of fishes in a regulated lowland tributary: Potential recruitment to the River Meuse. Hydrobiologia, 565(1), 105-120. https://doi.org/10.1007/s10750005-1908-4

Pracheil, B.M., Hogan, J.D., Lyons, J. \& McIntyre, P.B. (2014). Using hardpart microchemistry to advance conservation and management of North American freshwater fishes. Fisheries, 39(10), 451-465. https:// doi.org/10.1080/03632415.2014.937858

R Core Team. (2016). R: A language and environment for statistical computing. R Foundation for Statistical Computing.

Rahel, F.J. (2007). Biogeographic barriers, connectivity and homogenization of freshwater faunas: It's a small world after all. Freshwater Biology, 52(4), 696-710. https://doi.org/10.1111/j.13652427.2006.01708.x

Reichard, M. \& Jurajda, P. (2007). Seasonal dynamics and age structure of drifting cyprinid fishes: An interspecific comparison. Ecology of Freshwater Fish, 16(4), 482-492. https://doi.org/10.1111/j.16000633.2007.00229.x

Riquier, J., Piégay, H., Lamouroux, N. \& Vaudor, L. (2017). Are restored side channels sustainable aquatic habitat features? Predicting the potential persistence of side channels as aquatic habitats based on their fine sedimentation dynamics. Geomorphology, 295, 507-528. https://doi.org/10.1016/j.geomorph.2017.08.001 
Schiemer, F., Keckeis, H. \& Flore, L. (2001). Ecotones and hydrology: Key conditions for fish in large rivers. International Journal of Ecohydrology and Hydrobiology, 1(1), 49-55.

Schiemer, F., Keckeis, H., Reckendorfer, W. \& Winkler, G. (2001). The 'inshore retention concept' and its significance for large rivers. Archiv für Hydrobiologie, Supplement, 135(2), 509-516.

Schiemer, F. \& Spindler, T. (1989). Endangered fish species of the Danube River in Austria. Regulated Rivers: Research \& Management, 4(4), 397-407. https://doi.org/10.1002/rrr.3450040407

Schludermann, E., Tritthart, M., Humphries, P. \& Keckeis, H. (2012). Dispersal and retention of larval fish in a potential nursery habitat of a large temperate river: An experimental study. Canadian Journal of Fisheries and Aquatic Sciences, 69(8), 1302-1315. https://doi.org/10. 1139/f2012-061

Schmutz, S., Kremser, H., Melcher, A., Jungwirth, M., Muhar, S., Waidbacher, H. et al. (2014). Ecological effects of rehabilitation measures at the Austrian Danube: A meta-analysis of fish assemblages. Hydrobiologia, 729(1), 49-60. https://doi.org/10.1007/ s10750-013-1511-z

Sonny, D., Jorry, S., Wattiez, X. \& Philippart, J. (2006). Inter-annual and diel patterns of the drift of cyprinid fishes in a small tributary of the Meuse River, Belgium. Folia Zoologica, 55(1), 75-85.

Starrs, D., Ebner, B.C. \& Fulton, C.J. (2016). All in the ears: Unlocking the early life history biology and spatial ecology of fishes. Biological Reviews, 91(1), 86-105. https://doi.org/10.1111/brv.12162

Sturrock, A., Trueman, C., Milton, J., Waring, C., Cooper, M. \& Hunter, E. (2014). Physiological influences can outweigh environmental signals in otolith microchemistry research. Marine Ecology Progress Series, 500, 245-264. https://doi.org/10.3354/meps10699

Sturrock, A.M., Hunter, E., Milton, J.A., EIMF, Johnson, R.C., Waring, C.P. et al. (2015). Quantifying physiological influences on otolith microchemistry (E. Leder, Ed). Methods in Ecology and Evolution, 6(7), 806-816. https://doi.org/10.1111/2041-210X.12381

Tabouret, H., Bareille, G., Claverie, F., Pécheyran, C., Prouzet, P. \& Donard, O.F.X. (2010). Simultaneous use of strontium:calcium and barium:calcium ratios in otoliths as markers of habitat: Application to the European eel (Anguilla anguilla) in the Adour basin, South West France. Marine Environmental Research, 70(1), 35-45. https://doi.org/ 10.1016/j.marenvres.2010.02.006

Takada, M. \& Tachihara, K. (2009). Comparisons of age, growth, and maturity between male and female, and diploid and triploid individuals in Carassius auratus from Okinawa-jima Island, Japan. Aquatic Conservation: Marine and Freshwater Ecosystems, 19(7), 806-814. https://doi.org/10.1002/aqc.1032

Teichert, N., Tabouret, H., Lagarde, R., Grondin, H., Ponton, D., Pécheyran, C. et al. (2018). Site fidelity and movements of an amphidromous goby revealed by otolith multi-elemental signatures along a tropical watershed. Ecology of Freshwater Fish, 27(3), 834-846. https://doi.org/10.1111/eff.12396

Thorel, M., Piégay, H., Barthelemy, C., Räpple, B., Gruel, C.-R., Marmonier, P. et al. (2018). Socio-environmental implications of process-based restoration strategies in large rivers: Should we remove novel ecosystems along the Rhône (France)? Regional Environmental Change, 18(7), 2019-2031. https://doi.org/10.1007/s10113-018-1325-7

Tockner, K., Uehlinger, U. \& Robinson, C.T. (2009). Rivers of Europe. Amsterdam: Academic Press.

Torniainen, J., Vuorinen, P.J., Jones, R.I., Keinänen, M., Palm, S., Vuori, K.A. et al. (2013). Migratory connectivity of two Baltic Sea salmon populations: Retrospective analysis using stable isotopes of scales. ICES Journal of Marine Science, 71(2), 336-344. https://doi.org/10. 1093/icesjms/fst153

Vignon, M. (2015). Extracting environmental histories from sclerochronological structures - Recursive partitioning as a mean to explore multi-elemental composition of fish otolith. Ecological Informatics, 30, 159-169. https://doi.org/10.1016/j.ecoinf.2015.10.002

Vörösmarty, C.J. \& Sahagian, D. (2000). Anthropogenic disturbance of the terrestrial water cycle. Bioscience, 50(9), 753-765. https://doi.org/10. 1641/0006-3568(2000)050[0753:ADOTTW]2.0.CO;2

Wells, B., Rieman, B., Clayton, J., Horan, D. \& Jones, C. (2003). Relationships between water, otolith, and scale chemistries of Westslope Cutthroat Trout from the Coeur d'Alene River, Idaho: The potential application of hard-part chemistry to describe movements in freshwater. Transactions of the American Fisheries Society, 132(3), 409-424. https://doi.org/10.1577/1548-8659(2003) 132<0409:RBWOAS >2.0.CO;2

Whitledge, G.W., Knights, B., Vallazza, J., Larson, J., Weber, M.J., Lamer, J.T. et al. (2019). Identification of bighead carp and silver carp early-life environments and inferring Lock and Dam 19 passage in the Upper Mississippi River: Insights from otolith chemistry. Biological Invasions, 21(3), 1007-1020. https://doi.org/10.1007/s10530-0181881-2

Wolter, C. (2015). Historic catches, abundance, and decline of Atlantic salmon Salmo salar in the River Elbe. Aquatic Sciences, 77(3), 367-380. https://doi.org/10.1007/s00027-014-0372-5

Woodcock, S.H., Munro, A.R., Crook, D.A. \& Gillanders, B.M. (2012). Incorporation of magnesium into fish otoliths: Determining contribution from water and diet. Geochimica et Cosmochimica Acta, 94, 12-21. https://doi.org/10.1016/j.gca.2012.07.003

Xenopoulos, M.A., Lodge, D.M., Alcamo, J., Märker, M., Schulze, K. \& Vuuren, D.P.V. (2005). Scenarios of freshwater fish extinctions from climate change and water withdrawal. Global Change Biology, 11(10), 1557-1564. https://doi.org/10.1111/j.1365-2486.2005.001008.x

Yokouchi, K., Fukuda, N., Shirai, K., Aoyama, J., Daverat, F. \& Tsukamoto, K. (2011). Time lag of the response on the otolith strontium/calcium ratios of the Japanese eel, Anguilla japonica to changes in strontium/calcium ratios of ambient water. Environmental Biology of Fishes, 92(4), 469-478. https://doi.org/10.1007/s10641-011-9864-5

Zeigler, J.M. \& Whitledge, G.W. (2010). Assessment of otolith chemistry for identifying source environment of fishes in the lower Illinois River, Illinois. Hydrobiologia, 638(1), 109-119. https://doi.org/10.1007/ s10750-009-0033-1

Zens, B., Glas, M., Tritthart, M., Habersack, H. \& Keckeis, H. (2018). Movement patterns and rheoreaction of larvae of a fluvial specialist (nase, Chondrostoma nasus): The role of active versus passive components of behaviour in dispersal. Canadian Journal of Fisheries and Aquatic Sciences, 75(2), 193-200. https://doi.org/10.1139/cjfas2016-0276

\section{SUPPORTING INFORMATION}

Additional supporting information may be found online in the Supporting Information section at the end of this article.

How to cite this article: Bounket, B., Tabouret, H., Gibert, P., Bareille, G., Pecheyran, C., Carrel, G. et al. (2021). Spawning areas and migration patterns in the early life history of Squalius cephalus (Linnaeus, 1758): Use of otolith microchemistry for conservation and sustainable management. Aquatic Conservation: Marine and Freshwater Ecosystems, 31(10), 2772-2787. https://doi.org/10.1002/aqc.3682 